\title{
12. STRONTIUM-ISOTOPIC CORRELATION OF OLIGOCENE TO MIOCENE SEQUENCES, NEW JERSEY AND FLORIDA ${ }^{1}$
}

\author{
Peter J. Sugarman, ${ }^{2,3}$ Lucy McCartan, ${ }^{4}$ Kenneth G. Miller, ${ }^{3,5}$ Mark D. Feigenson, ${ }^{3}$ \\ Stephen Pekar, ${ }^{3}$ Ronald W. Kistler, ${ }^{6}$ and A.G. Robinson ${ }^{6}$
}

\begin{abstract}
We use Sr-isotopic age estimates to date siliciclastic, carbonate, and mixed siliciclastic-carbonate Oligocene and Miocene sequences for the New Jersey Coastal Plain and Florida Peninsula and to correlate sequence boundaries with the deep-sea $\delta^{18} \mathrm{O}$ record and the inferred eustatic record of Exxon. The New Jersey onshore Oligocene to lower Miocene sequences correlate reasonably well with the Florida Miocene sequences. However, the majority of middle Miocene sequences mapped in New Jersey are missing from central Florida. The age of Oligocene to Miocene sequence boundaries determined in continuous boreholes from New Jersey, Alabama, and Florida show excellent correlation with deep-sea $\delta^{18} \mathrm{O}$ increases, which are inferred glacioeustatic lowerings. This is strong confirmation that global sea-level change is a primary control on the timing of Oligocene to Miocene sequence boundaries for the coastal plain sections studied here.

Whereas global sea level has a significant influence on coastal plain sequences, there are major differences in the preservation of sequences within the same depositional basin (e.g., Salisbury Embayment) and between basins (e.g., Florida basins vs. Salisbury Embayment). These intra- and interbasinal differences must be ascribed to noneustatic processes such as tectonics or differential erosion. Tectonic mechanisms include faulting of crustal blocks, mobile basins with evolving arches and depocenters, local flexural subsidence, or differential subsidence caused by sediment loading.
\end{abstract}

\section{INTRODUCTION}

A major goal of the New Jersey Coastal Plain Drilling Project, Ocean Drilling Program (ODP) Leg 150X, is the study of global sealevel change during the Oligocene to Holocene "Icehouse World," an interval when ice-volume variations exerted significant control on changes in global sea-level (see Miller, Chapter 1, this volume). Oxygen isotopic records provide a precise means for calibrating sealevel changes to the geologic time scale for the last 35 m.y. (e.g., Miller et al., 1996b). However, the oxygen-isotope method can be affected by temperature and local salinity changes, and more importantly, provides no information on the influence or magnitude of tectonically induced sea-level changes (Miller and Mountain, 1994).

Comparing the stratigraphy of shallow-water siliciclastic and carbonate sequences on different passive continental margins provides another means for evaluating timing of sea-level events. Similar timing of interregional unconformities indicates a global cause. If these interregional unconformities correlate with $\delta^{18} \mathrm{O}$ increases, then a glacioeustatic control is indicated. However, shallow-water $(<100 \mathrm{~m})$ chronologic control is often limited because of problems with facies controls on magnetobiostratigraphy (Miller and Kent, 1987). Srisotope stratigraphy circumvents these problems and can provide a chronology for critical Oligocene to Holocene "Icehouse" sequences (Sugarman et al., 1993).

The New Jersey Coastal Plain provides a record of numerous Oligocene to middle Miocene sequences. Biostratigraphic correlations of Miocene sequences in New Jersey primarily rely on diatoms (Ab-

${ }^{1}$ Miller, K.G., and Snyder, S.W. (Eds.), 1997. Proc. ODP, Sci. Results, 150X: College Station, TX (Ocean Drilling Program).

\section{${ }^{2}$ New Jersey Geological Survey, CN 427, Trenton, NJ 08625, U.S.A.} petes@njgs.dep.state.nj.us U.S.A.

${ }^{3}$ Department of Geological Sciences, Rutgers University, Piscataway, NJ 08855 ,

${ }^{4}$ U.S. Geological Survey, MS 926, Reston, VA 22092, U.S.A. U.S.A.

${ }^{5}$ Lamont-Doherty Earth Observatory of Columbia University, Palisades, NY 10964 ,

${ }^{6}$ U.S. Geological Survey, 345 Middlefield Road, Menlo Park, CA 94025, U.S.A. bott, 1978; Andrews, 1988) that are not yet precisely calibrated to the time scale. Sugarman et al. (1993) applied Sr-isotopic studies to the first continuously cored boreholes in New Jersey, ACGS\#4 and Belleplain (Fig. 1), to decipher the sequence stratigraphy of the Miocene Kirkwood Formation and calibrate it to the time scale. Drilling of the Island Beach, Atlantic City, and Cape May boreholes by Leg $150 \mathrm{X}$ provided additional material to map and date Oligocene to Miocene sequences (Miller, et al., 1994, 1996a; Miller and Sugarman, 1995; Pekar and Miller, 1996). Correlation of these sequence boundaries with the deep-sea $\delta^{18} \mathrm{O}$ glacioeustatic proxy indicates a primary control by global sea level (Miller and Sugarman, 1995; Miller et al., 1996b; Miller et al., Chapter 1, this volume; Pekar and Miller, 1996).

Sr-isotope stratigraphy has also significantly improved the understanding of the middle Cenozoic history of Florida in the last two years (Jones et al., 1993; Mallinson et al., 1994; Scott et al., 1994; Wingard et al., 1994; Mallinson and Compton, 1995; McCartan et al., 1995c). For example, the lower half of the deposits assigned to the Hawthorn Group (Scott, 1988), previously thought to be Miocene, have yielded late Oligocene Sr-isotopic age estimates (Scott et al., 1994; Mallinson et al., 1994; McCartan et al., 1995c). Mallinson et al. (1994) investigated deposits in northeast Florida (where the Hawthorn Formation has not been divided), whereas Jones et al. (1993) studied northwest Florida. McCartan et al. (1995b, 1995c) and this study concentrate on strata in the central and southern Florida Peninsula.

This paper employs several approaches to focus on the timing of eustatic events recorded in the Atlantic Coastal Plain during the Oligocene-middle Miocene portion of the "Icehouse World." First, we present an Oligocene (from Pekar et al., Chapter 15, this volume) to Miocene (from this study and Miller et al., Chapter 14, this volume) sequence stratigraphic framework developed from Sr-isotopes, biostratigraphy, and geologic mapping of the three Leg 150X boreholes (Island Beach, Atlantic City, and Cape May) from the New Jersey Coastal Plain (Table 1). Emphasis is placed on determining the ages of sequence boundaries and duration of sequences. Second, we establish the age of Oligocene to Pliocene sequences and sequence boundaries in Florida using new (Table 2) and published Sr-isotope data 


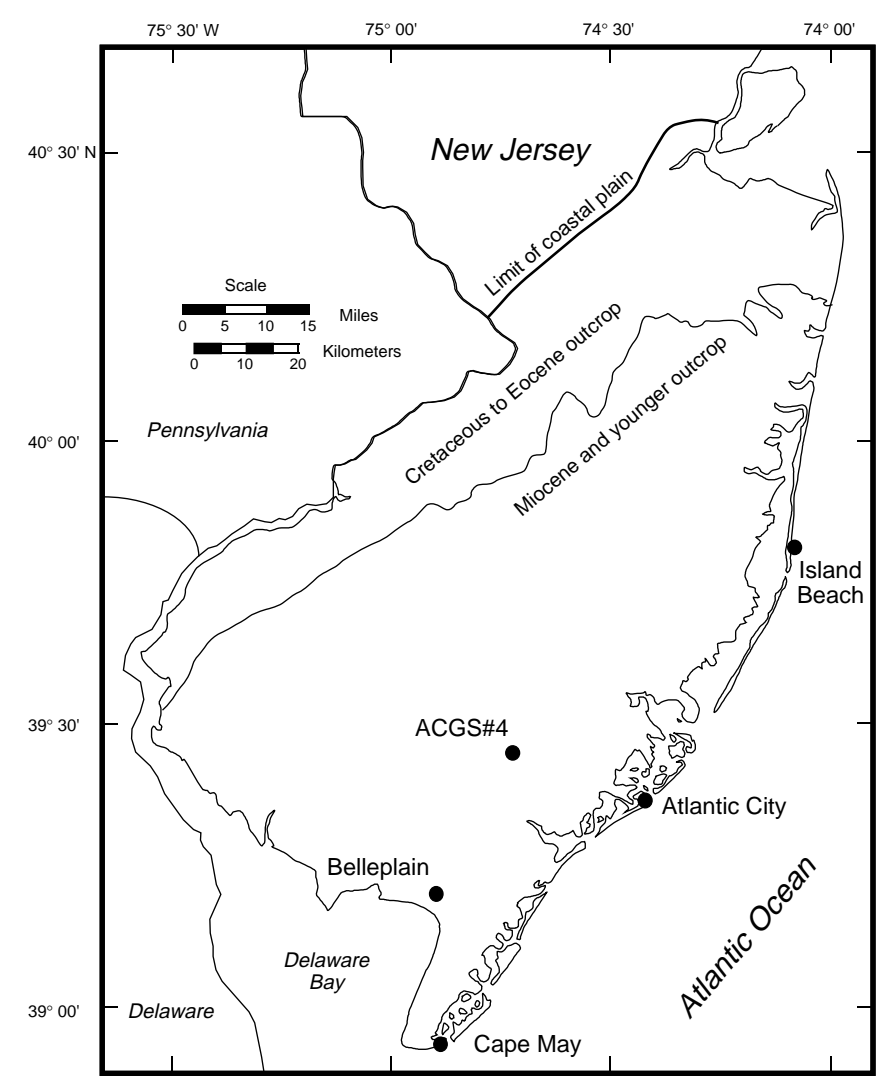

Figure 1. Location map of the New Jersey boreholes studied or referenced in this paper including the Leg 150X Island Beach, Atlantic City, and Cape May Sites.

from Florida (Jones et al., 1993; McCartan et al., 1995c) and records from Alabama (Miller et al., 1993). If coeval sequence boundaries exist along the length of the Atlantic and Gulf Coastal Plains, then timing of major eustatic events can be inferred. We also compare the combined New Jersey, Florida, and Alabama records with the deepsea $\delta^{18} \mathrm{O}$ and the Haq et al. (1987) inferred eustatic records. We conclude that similar events occur in all of these records, confirming eustasy as the primary control on depositional sequences. Nevertheless, basinal differences indicate that tectonics and differential erosion play an important role in determining the stratigraphic record.

\section{METHODS}

Samples were obtained from the Leg 150X Island Beach, Atlantic City, and Cape May boreholes (Fig. 1) at the Rutgers core facility in Piscataway, NJ (Table 1). Cores from Florida (Fig. 2) were sampled at the Florida Geological Survey's core repository in Tallahassee and are indexed according to the Florida Geological Survey's well accession numbering system (Table 2).

Sr-isotope analyses were made on calcareous mollusk shells (note: one sample was collected from foraminifers). A 0.1-in diameter $(5 \mathrm{~mm})$ piece was taken from the most pristine part of the shell and ultrasonically cleaned in distilled water for 5-10 s, crushed, and dissolved in 1.5-N HCl. Standard ion-exchange techniques (Hart and Brooks, 1974) were used to separate strontium for analysis on a VG Sector mass spectrometer at Rutgers University. At Rutgers, NBS987 was measured as $0.710255{ }^{87} \mathrm{Sr} /{ }^{86} \mathrm{Sr}(20$ analyses, $1 \sigma=$ \pm 0.000008 , normalized to ${ }^{86} \mathrm{Sr} /{ }^{88} \mathrm{Sr}=0.1194$ ) during analysis of Leg
150X samples. Two recent measurements on EN-1, an informal Srisotope standard, are $0.709196 \pm 9$ and $0.709186 \pm 6$.

Average internal error (intrarun variability) at Rutgers was \pm 0.000009 for the 103 and 17 samples analyzed and tabulated in Tables 1 and 2. External error at Rutgers has previously been reported as \pm 0.000020 to \pm 0.000030 (Miller et al., 1991a). In a recent study from the Rutgers laboratory, average error of 17 duplicates analyzed was \pm 0.000020 (Oslick et al., 1994); this is probably a good estimate for external precision.

Sr-isotopic values for Florida shells were measured at the Rutgers Laboratory, and the U.S. Geological Survey's Isotope Laboratory in Menlo Park, CA. At Menlo Park, samples were dissolved in 2-N HCl. Strontium-isotope ratios were determined using a MAT $261,90^{\circ}$ sector mass spectrometer, using the double rhenium filament mode of ionization. All Sr-isotopic ratios are also normalized to a ${ }^{86} \mathrm{Sr} /{ }^{88} \mathrm{Sr}=0.1194$. Lab average of ${ }^{87} \mathrm{Sr} /{ }^{86} \mathrm{Sr}$ for the NBS standard is $0.710239 \pm 14$; we add 0.000016 to ${ }^{87} \mathrm{Sr} /{ }^{86} \mathrm{Sr}$ measurements from the U.S. Geological Survey Isotope Laboratory for comparison with ${ }^{87} \mathrm{Sr} /{ }^{86} \mathrm{Sr}$ values from the Rutgers Laboratory (Table 2).

Sr-isotope values were converted to age estimates using the regression equations of Oslick et al. (1994) for the Oligocene through Miocene, and Miller et al. (1988) for the late Eocene. Late Miocene and Pliocene ages were determined using the data sets in Farrell et al. (1995), and converting these into age equations using the techniques outlined in Miller et al. (1991a). The equations are given in Table 3. The Oslick et al. (1994) regressions were computed for the Cande and Kent (1992) time scale, which has minor differences from the Berggren et al. (1995) time scale. The geomagnetic polarity time scale (GPTS) of Berggren et al. (1995) is used throughout.

Stratigraphic resolution in the Oligocene is as good as \pm 0.5 m.y. in the early Oligocene and as poor as $\pm 0.8 \mathrm{~m}$.y. for the late Oligocene interval between $\sim 28$ and $24 \mathrm{Ma}$ (Oslick et al., 1994). The early Miocene is especially suitable for Sr-isotope stratigraphy, with a ${ }^{87} \mathrm{Sr} /{ }^{86} \mathrm{Sr}$ rate of change of 60-80 ppm/m.y. (Hodell et al., 1991; Miller et al., 1991a; Oslick et al., 1994), and age estimates with a resolution of \pm 0.4 m.y. for replicate analyses (Oslick et al., 1994). Age resolution for the middle Miocene decreases to about $\pm 0.9 \mathrm{~m}$.y because of a corresponding lower ${ }^{87} \mathrm{Sr} /{ }^{86} \mathrm{Sr}$ rate of change $(\sim 22 \mathrm{ppm} / \mathrm{m}$.y; Oslick et al., 1994), but still provides moderate chronostratigraphic resolution.

Diagenetic alteration of the source material for the different data sets is a concern. For New Jersey samples, few diagenetic problems have been documented (Sugarman et al., 1993; Miller, et al., 1994). However, diagenetic problems were encountered in the Maryland Miocene section (Miller and Sugarman, 1995) and attributed to postdepositional exchanges in aragonitic shells. In Florida, Jones et al. (1993), McCartan et al. (1995c), and this paper present analyses of calcareous shallow-water shells, whereas Mallinson et al. (1994) analyzed dolomitic sediment and phosphorite grains and crusts. Nevertheless, all the authors conclude that their ${ }^{87} \mathrm{Sr} /{ }^{86} \mathrm{Sr}$ values reflect the times when sea level was at or near its maximum for the depositional cycle during which the sample was formed.

Age inversions are present in certain intervals from boreholes in Florida. The nonsystematic pattern of $\mathrm{Sr}$-isotopic values in Borehole $\mathrm{W}-16505$ above $663.2 \mathrm{ft}(202.1 \mathrm{~m})$ may indicate diagenetic overprinting or reworking. With the exception of these problems, the Florida data can be interpreted in a stratigraphically meaningful way.

\section{RESULTS \\ New Jersey Depositional Styles}

Both Oligocene and Miocene sequences from the Leg 150X onshore boreholes show similar overall coarsening-upward trends above basal unconformities. These asymmetric transgressive/regressive cycles of sedimentation have been documented by Owens and 
Table $1 .{ }^{87} \mathrm{Sr} /{ }^{86} \mathrm{Sr}$ values and age estimates for the Atlantic City, Island Beach, and Cape May boreholes.

\begin{tabular}{|c|c|c|c|c|c|c|}
\hline $\begin{array}{l}\text { Rutgers } \\
\text { lab no. }\end{array}$ & $\begin{array}{l}\text { Depth } \\
\text { (ft) }\end{array}$ & ${ }^{87} \mathrm{Sr} /{ }^{86} \mathrm{Sr}$ & Error $( \pm)$ & $\begin{array}{l}\text { BKV age } \\
\text { (Ma) }\end{array}$ & $\begin{array}{c}\text { CK age } \\
\text { (Ma) }\end{array}$ & $\begin{array}{c}\text { Age error } \\
\text { Ma }( \pm)\end{array}$ \\
\hline \multicolumn{7}{|l|}{ Cape May } \\
\hline 2039 & 358.4 & 0.708856 & 0.000006 & 12.5 & 12.7 & 1.2 \\
\hline 2033 & 370.4 & 0.708880 & 0.000008 & 11.4 & 11.8 & 1.2 \\
\hline 2034 & 386.7 & 0.708885 & 0.000008 & 11.2 & 11.6 & 1.2 \\
\hline 2035 & 390.6 & 0.708870 & 0.000009 & 11.9 & 12.2 & 1.2 \\
\hline 1966 & $417.1 \mathrm{a}$ & 0.708878 & 0.000007 & 11.5 & 11.9 & 1.2 \\
\hline 1967 & $417.1 \mathrm{~b}$ & 0.708887 & 0.000013 & 11.1 & 11.5 & 1.2 \\
\hline 1968 & 421.4 & 0.708878 & 0.000006 & 11.5 & 11.9 & 1.2 \\
\hline 1969 & 431.5 & 0.708878 & 0.000007 & 11.5 & 11.9 & 1.2 \\
\hline 2213 & 514.3 & 0.708790 & 0.000008 & 15.5 & 15.2 & 1.2 \\
\hline 2214 & 527.5 & 0.708812 & 0.000013 & 14.5 & 14.4 & 1.2 \\
\hline 1970 & 529.5 & 0.708805 & 0.000025 & 14.8 & 14.6 & 1.2 \\
\hline 2111 & 573.6 & 0.708816 & 0.000011 & 14.3 & 14.2 & 1.2 \\
\hline 2112 & 581.5 & 0.708766 & 0.000008 & 16.2 & 15.9 & 0.6 \\
\hline 2162 & 582.6 & 0.708784 & 0.000027 & 16.0 & 15.7 & 0.6 \\
\hline 2036 & 600.0 & 0.708764 & 0.000011 & 16.3 & 16.0 & 0.6 \\
\hline 2040 & 677.3 & 0.708721 & 0.000006 & 16.9 & 16.6 & 0.6 \\
\hline 2298 & 690.1 & 0.708685 & 0.000012 & 17.4 & 17.1 & 0.6 \\
\hline 2113 & 706.4 & 0.708659 & 0.000007 & 17.8 & 17.5 & 0.6 \\
\hline 2041 & 722.5 & 0.708601 & 0.000008 & 18.6 & 18.4 & 0.6 \\
\hline 2037 & 810.9 & 0.708558 & 0.000010 & 19.3 & 19.0 & 0.6 \\
\hline 2042 & 832.6 & 0.708540 & 0.000007 & 19.5 & 19.3 & 0.6 \\
\hline 2030 & 851.3 & 0.708499 & 0.000014 & 20.1 & 19.9 & 0.6 \\
\hline 2038 & 882.7 & 0.708498 & 0.000008 & 20.1 & 19.9 & 0.6 \\
\hline 2043 & 982.2 & 0.708476 & 0.000011 & 20.4 & 20.2 & 0.6 \\
\hline 2044 & 1012.7 & 0.708448 & 0.000007 & 20.8 & 20.6 & 0.6 \\
\hline 2027 & 1058.0 & 0.708446 & 0.000009 & 20.9 & 20.6 & 0.6 \\
\hline 2045 & 1058.0 & 0.708438 & 0.000077 & 21.0 & 20.7 & 0.6 \\
\hline 2046 & 1085.0 & 0.708323 & 0.000014 & 22.6 & 22.4 & 0.6 \\
\hline 2028 & 1085.0 & 0.708318 & 0.000029 & 22.7 & 22.5 & 0.6 \\
\hline 2031 & 1098.0 & 0.708327 & 0.000016 & 22.6 & 22.4 & 0.6 \\
\hline 2047 & 1098.0 & 0.708334 & 0.000020 & 22.5 & 22.3 & 0.6 \\
\hline 2114 & 1135.8 & 0.708290 & 0.000006 & 23.1 & 23.6 & 1.1 \\
\hline 2032 & 1209.0 & 0.708228 & 0.000014 & 25.0 & 24.8 & 1.1 \\
\hline 2048 & 1209.0 & 0.708229 & 0.000029 & 24.9 & 24.7 & 1.1 \\
\hline 2183 & 1209.0 & 0.708315 & 0.000019 & 22.5 & 23.1 & 1.1 \\
\hline 2029 & 1247.0 & 0.708257 & 0.000006 & 24.1 & 24.2 & 1.1 \\
\hline 2185 & 1249.0 & 0.708251 & 0.000011 & 24.3 & 24.3 & 1.1 \\
\hline 2180 & 1268.0 & 0.708335 & 0.000038 & 21.9 & 22.7 & 1.1 \\
\hline 2139 & 1271.0 & 0.708216 & 0.000008 & 25.3 & 25.0 & 1.1 \\
\hline 2140 & 1299.0 & 0.708223 & 0.000014 & 25.1 & 24.9 & 1.1 \\
\hline 2141 & 1302.0 & 0.708178 & 0.000006 & 26.4 & 25.7 & 1.1 \\
\hline 2142 & 1340.0 & 0.708034 & 0.000013 & 30.6 & 28.5 & 1.1 \\
\hline 2186 & 1340.0 & 0.707995 & 0.000030 & 31.7 & 30.1 & 2.0 \\
\hline 2143 & 1350.0 & 0.707939 & 0.000008 & 33.3 & 31.6 & 2.0 \\
\hline 2181 & 1350.0 & 0.70794 & 0.000031 & 33.3 & 31.6 & 2.0 \\
\hline 2182 & 1354.5 & 0.707973 & 0.000020 & 32.3 & 30.7 & 2.0 \\
\hline \multicolumn{7}{|c|}{ Island Beach } \\
\hline 1700 & 503.3 & 0.708390 & 0.000015 & 21.7 & 21.4 & 0.6 \\
\hline 1701 & 504.5 & 0.708379 & 0.000004 & 21.8 & 21.6 & 0.6 \\
\hline 1702 & 522.5 & 0.708252 & 0.000005 & 24.3 & 24.3 & 1.1 \\
\hline 1703 & 663.8 & 0.707958 & 0.000006 & 32.7 & 31.1 & 2.0 \\
\hline 1745 & 668.0 & 0.707957 & 0.000012 & 32.8 & 31.1 & 2.0 \\
\hline
\end{tabular}

\begin{tabular}{|c|c|c|c|c|c|c|}
\hline $\begin{array}{l}\text { Rutgers } \\
\text { lab no. }\end{array}$ & $\begin{array}{c}\text { Depth } \\
\text { (ft) }\end{array}$ & ${ }^{87} \mathrm{Sr} /{ }^{86} \mathrm{Sr}$ & Error $( \pm)$ & $\begin{array}{l}\text { BKV age } \\
\text { (Ma) }\end{array}$ & $\begin{array}{c}\text { CK age } \\
\text { (Ma) }\end{array}$ & $\begin{array}{c}\text { Age error } \\
\mathrm{Ma}( \pm)\end{array}$ \\
\hline 1746 & 677.0 & 0.707944 & 0.000014 & 33.1 & 31.5 & 2.0 \\
\hline 1704 & 683.6 & 0.707983 & 0.000006 & 32.0 & 30.4 & 2.0 \\
\hline 2187 & 703.0 & 0.707743 & 0.000034 & 38.9 & 37.0 & 2.0 \\
\hline \multicolumn{7}{|l|}{ Atlantic City } \\
\hline 1786 & 401.7 & 0.708839 & 0.000013 & 13.3 & 13.4 & 1.2 \\
\hline 1792 & 411.1 & 0.708836 & 0.000009 & 13.4 & 13.5 & 1.2 \\
\hline 1907 & 442.5 & 0.708842 & 0.000012 & 13.1 & 13.2 & 1.2 \\
\hline 1908 & 462.6 & 0.708827 & 0.000008 & 13.8 & 13.8 & 1.2 \\
\hline 1787 & 462.6 & 0.708833 & 0.000010 & 13.5 & 13.6 & 1.2 \\
\hline 1884 & 476.5 & 0.708765 & 0.000006 & 16.6 & 16.0 & 0.6 \\
\hline 1965 & 479.0 & 0.708798 & 0.000008 & 15.1 & 15.5 & 0.6 \\
\hline 1885 & 492.3 & 0.708762 & 0.000007 & 16.7 & 16.0 & 0.6 \\
\hline 1819 & 515.0 & 0.708765 & 0.000033 & 16.6 & 16.0 & 0.6 \\
\hline 1913 & 519.5 & 0.708722 & 0.000009 & 18.5 & 16.6 & 0.6 \\
\hline 1788 & 520.0 & 0.708713 & 0.000011 & 17.0 & 16.7 & 0.6 \\
\hline 1793 & 559.7 & 0.708668 & 0.000011 & 17.7 & 17.4 & 0.6 \\
\hline 1820 & 605.1 & 0.708656 & 0.000011 & 17.8 & 17.6 & 0.6 \\
\hline 1794 & 644.0 & 0.708672 & 0.000008 & 17.6 & 17.3 & 0.6 \\
\hline 1909 & 644.1 & 0.708669 & 0.000009 & 17.6 & 17.4 & 0.6 \\
\hline 1826 & 661.1 & 0.708640 & 0.000008 & 18.1 & 17.8 & 0.6 \\
\hline 1825 & 661.2 & 0.708494 & 0.000010 & 20.2 & 19.9 & 0.6 \\
\hline 1795 & 708.5 & 0.708476 & 0.000011 & 20.4 & 20.2 & 0.6 \\
\hline 1914 & 708.5 & 0.708485 & 0.000007 & 20.3 & 20.1 & 0.6 \\
\hline 1796 & 723.2 & 0.708490 & 0.000010 & 20.2 & 20.0 & 0.6 \\
\hline 1910 & 723.2 & 0.708488 & 0.000010 & 20.3 & 20.0 & 0.6 \\
\hline 1821 & 821.2 & 0.708469 & 0.000010 & 20.5 & 20.3 & 0.6 \\
\hline 1822 & 831.4 & 0.708468 & 0.000011 & 20.6 & 20.3 & 0.6 \\
\hline 1915 & 831.4 & 0.708482 & 0.000015 & 20.3 & 20.1 & 0.6 \\
\hline 1789 & 854.1 & 0.708453 & 0.000011 & 20.8 & 20.5 & 0.6 \\
\hline 1911 & 854.1 & 0.708484 & 0.000010 & 20.3 & 20.1 & 0.6 \\
\hline 1847 & 869.2 & 0.708438 & 0.000020 & 21.0 & 20.7 & 0.6 \\
\hline 1953 & 875.1 & 0.708461 & 0.000012 & 20.7 & 20.4 & 0.6 \\
\hline 1790 & 884.8 & 0.708372 & 0.000012 & 21.9 & 21.7 & 0.6 \\
\hline 1916 & 884.8 & 0.708419 & 0.000020 & 21.3 & 21.0 & 0.6 \\
\hline 1889 & 898.0 & 0.708339 & 0.000009 & 22.4 & 22.2 & 0.6 \\
\hline 1848 & 908.3 & 0.708299 & 0.000011 & 22.9 & 23.4 & 1.1 \\
\hline 1791 & 913.0 & 0.708303 & 0.000011 & 22.8 & 23.3 & 1.1 \\
\hline 1954 & 913.0 & 0.708273 & 0.000011 & 23.7 & 23.9 & 1.1 \\
\hline 2297 & 917.5 & 0.708154 & 0.000038 & 27.1 & 26.2 & 1.1 \\
\hline 1890 & 922.5 & 0.708207 & 0.000026 & 25.6 & 25.2 & 1.1 \\
\hline 1823 & 932.2 & 0.708199 & 0.000013 & 25.8 & 25.3 & 1.1 \\
\hline 1955 & 948.0 & 0.708172 & 0.000007 & 26.6 & 25.9 & 1.1 \\
\hline 1797 & 974.5 & 0.708142 & 0.000011 & 27.4 & 26.4 & 1.1 \\
\hline 1956 & 974.5 & 0.708147 & 0.000012 & 27.3 & 26.3 & 1.1 \\
\hline 1824 & 1056.5 & 0.708135 & 0.000013 & 27.6 & 26.6 & 1.1 \\
\hline 2184 & 1072.0 & 0.708121 & 0.000011 & 28.1 & 26.8 & 1.1 \\
\hline 1827 & 1117.0 & 0.708097 & 0.000014 & 28.7 & 27.3 & 1.1 \\
\hline 1886 & 1140.9 & 0.708048 & 0.000007 & 30.2 & 28.3 & 1.08 \\
\hline 1887 & 1164.5 & 0.708056 & 0.000008 & 29.9 & 28.1 & 1.08 \\
\hline 1828 & 1178.2 & 0.707936 & 0.000008 & 33.4 & 30.4 & 2.0 \\
\hline 1829 & 1204.1 & 0.707823 & 0.000013 & 36.6 & 32.6 & 2.0 \\
\hline 1830 & 1301.1 & 0.707784 & 0.000013 & 37.7 & 33.4 & 2.0 \\
\hline 1888 & 1334.8 & 0.707763 & 0.000007 & 38.3 & 33.8 & 2.0 \\
\hline
\end{tabular}

Sohl (1969) for the Cretaceous and Sugarman et al. (1993) for the Miocene of New Jersey.

The Oligocene and Miocene sections reflect two different depositional systems: shelf and delta (see fig. 4 in Miller, Chapter 1, this volume). Oligocene sequences were deposited in neritic (shelfal) environments and often contain glauconite throughout. The presence of glauconite in the medial silts and upper quartz sands (Highstand Systems Tracts) is attributed to stratigraphic reworking (Pekar et al., Chapter 15 , this volume). Miocene sequences were deposited in shelfal and deltaic environments, and overall are characteristically shallower water deposits. Oligocene sediments often contain sufficient planktonic foraminifers for biostratigraphic correlation, whereas the Miocene strata mostly lack planktonic foraminifers (Liu et al., Chapter 10, this volume).

Oligocene sedimentation in the New Jersey Coastal Plain displays an overall coarsening-upward trend over several sequences. Owens et al. (1995a) mapped two subsurface Oligocene cycles, a lower Oligocene $\mathrm{To}_{1}$ cycle and an upper Oligocene $\mathrm{To}_{2}$ cycle, which approximately correspond to the Sewell Point and Atlantic City Formations (Pekar et al., Chapter 8, this volume). Pekar et al. (Chapter 15, this volume) recognized at least five Oligocene sequences using shifts in benthic foraminiferal biofacies along with hiatuses delineated biostratigraphically or with Sr isotopes. The lower Oligocene (Sewell
Point $/ \mathrm{To}_{1}$ cycle) is generally finer grained and characterized by outer neritic biofacies, whereas the upper Oligocene (Atlantic City/ $\mathrm{To}_{2}$ cycle) is generally coarser grained and characterized by inner (and some middle) neritic biofacies (Owens et al., 1995a; Pekar et al., Chapter 15 , this volume). Thus, the Oligocene of New Jersey shows a general coarsening and shallowing upsection that marks a major change in sedimentation. This increased input of coarse clastic material is associated with regional uplift of the Appalachians, which provided a renewed source of sediment (Poag and Sevon, 1989).

The lowermost Miocene Kw0 sequence is similar to Oligocene sequences in that it is dominated by glauconite deposited in inner to middle neritic paleodepths (Miller, et al., 1994). It has only been mapped downdip in continuously cored boreholes (e.g., Atlantic City and Cape May; Miller and Sugarman, 1995).

Miocene sedimentation younger than $22 \mathrm{Ma}$ in New Jersey reflects strong deltaic influence. The Kw1 (Kirkwood 1) and younger Miocene sequences record shoaling-upward transitions from inner neritic and prodelta environments to delta front and near-shore marine environments. The lower Miocene Kw1 sequences (Kw1a and $\mathrm{Kw} 1 \mathrm{~b})$ are the most extensive sequences in New Jersey and are exposed updip in the outcrop belt (Sugarman et al., 1993; Owens et al., 1995a, 1995b). Both the Kw1a and Kw1b sequences are dominated by silt facies deposited in neritic environments in their lower and me- 
Table 2. New ${ }^{87} / \mathrm{Sr}^{86} \mathrm{Sr}$ values, age estimates, and sequence correlation for boreholes studied in central and southern Florida (Fig. 2).

\begin{tabular}{|c|c|c|c|c|c|c|c|}
\hline Core & $\begin{array}{c}\text { Depth } \\
\text { (ft) }\end{array}$ & ${ }^{87} \mathrm{Sr} /{ }^{86} \mathrm{Sr}$ & \pm & $\begin{array}{c}\text { Interlab } \\
\text { correction } \\
+0.000016\end{array}$ & $\begin{array}{c}\text { BKV85 } \\
\text { Age } \\
\text { (Ma) }\end{array}$ & $\begin{array}{c}\text { BKV95 } \\
\text { Age } \\
\text { (Ma) }\end{array}$ & Sequence \\
\hline W-11669 & 39.0 & 0.708381 & 25 & 0.708397 & 21.6 & 21.3 & FM1 \\
\hline W-11669 & 54.0 & 0.707994 & 19 & 0.708010 & 31.2 & 29.7 & FM1-diagenesis \\
\hline W-11669 & 166.2 & 0.707923 & 18 & 0.707939 & 33.3 & 31.6 & FM1-diagenesis \\
\hline W-11669 & 219.0 & 0.708359 & 13 & 0.708375 & 21.9 & 21.7 & FM1 \\
\hline W-11669 & 275.0 & 0.708381 & 42 & 0.708397 & 21.6 & 21.3 & FM1 \\
\hline W-11669 & 276.5 & 0.708374 & 15 & 0.708390 & 21.7 & 21.5 & FM1 \\
\hline W-11669 & 323.5 & 0.708327 & 23 & 0.708343 & 22.4 & 22.1 & FM1 \\
\hline W-11669 & 369.0 & 0.708069 & 12 & 0.708085 & 29.1 & 27.5 & $\mathrm{FO} 2 \mathrm{~b}$ \\
\hline W-11669 & 388.5 & 0.708136 & 19 & 0.708152 & 27.2 & 26.3 & $\mathrm{FO} 3$ \\
\hline W-11669 & 414.0 & 0.708032 & 19 & 0.708048 & 30.2 & 28.6 & $\mathrm{FO} 2$ \\
\hline W-11669 & 436.0 & 0.707989 & 15 & 0.708005 & 31.4 & 29.8 & $\mathrm{FO} 2$ \\
\hline W-11946 & 181.5 & 0.708101 & 18 & & 28.6 & 27.2 & $\mathrm{FO} 2 \mathrm{~b}$ \\
\hline W-11946 & 460.0 & 0.707853 & 8 & & 35.8 & 35.7 & Unnamed Eocene \\
\hline W-12050 & 56.0 & 0.708679 & 14 & 0.708695 & 17.3 & 17.0 & Diagenesis \\
\hline W- 12050 & $82-87$ & 0.708980 & 6 & None & & 5.1 & Unnamed \\
\hline W- 12050 & 85.0 & 0.708980 & 11 & 0.708996 & & 6.2 & Unnamed \\
\hline W- 12050 & 124.0 & 0.708569 & 18 & 0.708585 & 18.9 & 18.6 & FM2 \\
\hline W-12050 & 160.0 & 0.708524 & 20 & 0.708540 & 19.5 & 19.3 & FM2 \\
\hline W-12050 & 188.0 & 0.708534 & 10 & None & 19.7 & 19.3 & FM2 \\
\hline W-12050 & 226.0 & 0.708505 & 14 & 0.708521 & 19.8 & 19.5 & FM2 \\
\hline W-12050 & 268.0 & 0.708421 & 17 & 0.708437 & 21.0 & 20.8 & FM2 \\
\hline W-12050 & 277.0 & 0.708390 & 18 & 0.708406 & 21.4 & 21.2 & FM1 \\
\hline W-12050 & 286.0 & 0.708379 & 4 & None & 22.3 & 21.6 & FM1 \\
\hline $\mathrm{W}-12050$ & 355.5 & 0.708046 & 16 & 0.708062 & 28.0 & 28.0 & $\mathrm{FO} 2 \mathrm{~b}$ \\
\hline W-12050 & 400.0 & 0.707984 & 13 & 0.708000 & 29.7 & 30.0 & $\mathrm{FO} 2$ \\
\hline W- 12050 & 432.0 & 0.708002 & 11 & 0.708018 & 29.5 & 29.4 & $\mathrm{FO} 2$ \\
\hline W-12050 & 507.0 & 0.707835 & 17 & 0.707851 & 34.0 & 34.0 & Unnamed Eocene \\
\hline $\mathrm{W}-12050$ & 586.0 & 0.707927 & 8 & None & 33.6 & 33.6 & Unnamed Eocene \\
\hline W-15166 & 286.4 & 0.708324 & 8 & None & 22.9 & 22.2 & FM1 \\
\hline W-15168 & 381.5 & 0.708127 & 5 & None & 27.9 & 26.7 & FO3 \\
\hline W-15303 & 105.0 & 0.708588 & 10 & 0.708604 & 18.6 & 18.3 & FM2 \\
\hline W-15303 & 230.0 & 0.708052 & 41 & 0.708068 & 29.6 & 27.9 & $\mathrm{FO} 2 \mathrm{~b}$ \\
\hline W-15303 & 309.5 & 0.707985 & 27 & 0.708001 & 31.5 & 29.9 & $\mathrm{FO} 2$ \\
\hline W-15303 & 342.5 & 0.707968 & 16 & 0.707984 & 32.0 & 30.4 & $\mathrm{FO} 2$ \\
\hline W- 15303 & 433.0 & 0.708015 & 13 & 0.708031 & 30.6 & 29.1 & FO2-diagenesis \\
\hline W-15303 & 528.5 & 0.707920 & 19 & 0.707936 & 33.4 & 31.7 & FO1 \\
\hline W-15303 & 594.0 & 0.707904 & 19 & 0.707920 & 33.8 & 32.1 & FO1 \\
\hline W-15303 & 693.0 & 0.707888 & 19 & 0.707904 & 34.3 & 32.6 & FO1 \\
\hline $\mathrm{W}-15303$ & 825.0 & 0.707828 & 10 & 0.707844 & 36.5 & 34.2 & Unnamed Eocene \\
\hline W-15286 & 25.0 & 0.709003 & 19 & 0.709019 & & 5.7 & Unnamed \\
\hline W-15286 & 80.0 & 0.709033 & 16 & 0.709049 & & 5.0 & Unnamed \\
\hline W-15286 & 153.0 & 0.708894 & 13 & 0.708910 & 10.1 & 10.7 & FM5 \\
\hline W-15286 & 161.0 & 0.708859 & 13 & 0.708875 & 11.7 & 12.0 & FM5 \\
\hline W-15286 & 239.0 & 0.708761 & 17 & 0.708777 & 16.1 & 15.8 & FM4 \\
\hline W-15286 & $276-278.0$ & 0.708699 & 15 & 0.708715 & 17.0 & 16.7 & FM3 \\
\hline W-15286 & $307-309.0$ & 0.708770 & 14 & 0.708786 & 16.0 & 15.7 & Diagenesis \\
\hline W-15286 & 361.0 & 0.708704 & 14 & 0.708720 & 16.9 & 16.6 & FM3 \\
\hline W-15286 & 474.0 & 0.708619 & 16 & 0.708634 & 18.2 & 19.9 & FM2 \\
\hline W-15286 & 551.0 & 0.708431 & 28 & 0.708447 & 20.9 & 20.6 & FM2 \\
\hline W-15286 & 569.0 & 0.708415 & 17 & 0.708431 & 21.1 & 20.9 & FM2 \\
\hline W-15286 & 630.0 & 0.708187 & 19 & 0.708203 & 25.7 & 25.3 & FO3 \\
\hline W-15286 & 709.5 & 0.708162 & 17 & 0.708178 & 26.4 & 25.7 & FO3 \\
\hline W-15287 & 14.0 & 0.709075 & 14 & 0.709091 & & 2.2 & Unnamed \\
\hline W-15287 & 30.0 & 0.709075 & 13 & 0.709091 & & 2.2 & Unnamed \\
\hline W-15287 & 88.5 & 0.709014 & 18 & 0.709030 & & 5.4 & Unnamed \\
\hline W-15287 & 116.5 & 0.709041 & 12 & 0.709057 & & 4.8 & Unnamed \\
\hline W- 15287 & 131.0 & 0.709041 & 20 & 0.709057 & & 4.8 & Unnamed \\
\hline W-15287 & 162.0 & 0.709020 & 15 & 0.709036 & & 5.3 & Unnamed \\
\hline W-15287 & 197.0 & 0.709025 & 18 & 0.709041 & & 5.2 & Unnamed \\
\hline W-15287 & 320.0 & 0.708936 & 34 & 0.708952 & & 7.2 & Unnamed \\
\hline W-15636 & 295.0 & 0.708595 & 13 & & 18.9 & 18.4 & FM3 \\
\hline W-16505 & 20.0 & 0.709039 & 15 & 0.709054 & & 4.9 & Unnamed \\
\hline W-16505 & 58.5 & 0.709067 & 20 & 0.709083 & & 2.3 & Unnamed \\
\hline W-16505 & 72.5 & 0.709094 & 13 & 0.709110 & & 1.8 & Unnamed \\
\hline W-16505 & 273.9 & 0.708912 & 17 & 0.708928 & 9.3 & 10.0 & Unnamed \\
\hline W-16505 & 460.0 & 0.708813 & 22 & 0.708829 & 13.7 & 13.7 & Diagenesis? \\
\hline W-16505 & 483.0 & 0.708719 & 27 & 0.708935 & 9.0 & 9.7 & Diagenesis? \\
\hline W-16505 & 520.0 & 0.708581 & 18 & 0.708597 & 18.7 & 18.4 & Diagenesis \\
\hline W-16505 & 570.0 & 0.708734 & 14 & 0.708750 & 16.5 & 16.2 & FM4 \\
\hline W-16505 & 595.0 & 0.708692 & 22 & 0.708708 & 17.1 & 16.8 & FM3 \\
\hline W-16505 & 610.0 & 0.708650 & 30 & 0.708666 & 17.7 & 17.4 & FM3 \\
\hline W-16505 & 648.0 & 0.708643 & 13 & 0.708659 & 17.8 & 17.5 & FM3 \\
\hline W-16505 & 663.2 & 0.708796 & 15 & 0.708812 & 14.5 & 14.4 & Diagenesis \\
\hline W-16505 & 673.0 & 0.708630 & 17 & 0.708646 & 18 & 17.7 & FM3 \\
\hline W-16505 & 696.0 & 0.708626 & 17 & 0.708642 & 18 & 17.8 & FM3 \\
\hline W-16782 & 230.0 & 0.708192 & 6 & & 26.0 & 25.5 & FO3 \\
\hline W-16782 & 260.0 & 0.708182 & 6 & & 26.3 & 25.7 & FO3 \\
\hline W-16782 & 310.8 & 0.708153 & 6 & & 27.1 & 26.2 & $\mathrm{FO} 3$ \\
\hline W-16782 & 317.1 & 0.708163 & 8 & & 26.8 & 26.0 & FO3 \\
\hline
\end{tabular}


Table 2 (continued).

\begin{tabular}{|c|c|c|c|c|c|c|c|}
\hline Core & $\begin{array}{c}\text { Depth } \\
\text { (ft) }\end{array}$ & ${ }^{87} \mathrm{Sr} /{ }^{86} \mathrm{Sr}$ & \pm & $\begin{array}{c}\text { Interlab } \\
\text { correction } \\
+0.000016\end{array}$ & $\begin{array}{c}\text { BKV85 } \\
\text { Age } \\
\text { (Ma) }\end{array}$ & $\begin{array}{c}\text { BKV95 } \\
\text { Age } \\
\text { (Ma) }\end{array}$ & Sequence \\
\hline W-16814 & 234.0 & 0.708504 & 12 & 0.708520 & 19.8 & 19.5 & FM2 \\
\hline W-16814 & $341.5^{\prime}$ & 0.708181 & 6 & 0.708197 & & 25.4 & FO3 \\
\hline W-16814 & 388.5 & 0.808166 & 5 & & 26.8 & 26.0 & FO3 \\
\hline W-16814 & 630.0 & 0.708030 & 12 & 0.708046 & & 28.7 & $\mathrm{FO} 2$ \\
\hline W-16814 & 659.0 & 0.708042 & 5 & & 30.3 & 28.4 & $\mathrm{FO} 2$ \\
\hline W-16814 & 684.0 & 0.707980 & 20 & 0.707996 & & 30.1 & $\mathrm{FO} 2$ \\
\hline W-17000 & 313.0 & 0.708730 & 7 & & 16.7 & 16.5 & FM3 \\
\hline W- 17000 & 347.0 & 0.708409 & 20 & 0.708425 & 21.2 & 20.9 & FM2 \\
\hline W- 17000 & 374.0 & 0.708216 & 9 & & 25.3 & 25.0 & FO3 \\
\hline W-17000 & 423.0 & 0.707965 & 13 & 0.707981 & 32.1 & 30.5 & $\mathrm{FO} 2$ \\
\hline W- 17000 & 536.0 & 0.707863 & 19 & 0.707879 & 35.0 & 33.3 & FO1 \\
\hline W- 17000 & 636.5 & 0.707871 & 17 & 0.707887 & 34.8 & 33.0 & FO1 \\
\hline W- 17000 & 698.5 & 0.707773 & 24 & 0.707789 & 37.6 & 35.7 & Unnamed Eocene \\
\hline W-16890 & 80.0 & 0.709075 & 22 & 0.709091 & & 2.2 & Unnamed \\
\hline W-16890 & 143.0 & 0.709054 & 20 & 0.709070 & & 3.6 & Unnamed \\
\hline W-16890 & 409.0 & 0.708876 & 12 & 0.708892 & 10.9 & 11.3 & FM5 \\
\hline W-16890 & 570.5 & 0.708764 & 27 & 0.708780 & 16.1 & 15.7 & FM4 \\
\hline W-16890 & 614.0 & 0.708754 & 16 & 0.708770 & 16.2 & 15.9 & FM4 \\
\hline W-16890 & 765.5 & 0.708535 & 21 & 0.708551 & 19.4 & 19.1 & FM2 \\
\hline W-16890 & 797.5 & 0.708494 & 29 & 0.708510 & 19.9 & 19.7 & FM2 \\
\hline W-16890 & 898.0 & 0.708448 & 29 & 0.708464 & 20.6 & 20.4 & FM2 \\
\hline W-16890 & 960.0 & 0.708383 & 13 & 0.708399 & 21.5 & 21.3 & FM1 \\
\hline
\end{tabular}

dial parts and are capped by inner neritic and delta front quartz sands. The upper lower Miocene to lower middle Miocene Kw2 sequences (Kw2a and $\mathrm{Kw} 2 \mathrm{~b}$ ) are predominantly fine-grained facies deposited in inner neritic shelf and prodelta environments and are capped by quartz sands (maximum $50 \mathrm{ft}[15.2 \mathrm{~m}]$ ) in localized depocenters. One depocenter is localized in southeastern New Jersey (Cape May County); updip from this deposits of quartz sand from the Kw2 sequence occur, although their distribution is still poorly mapped. Miocene sequences younger than the Kw2 (the Kw3 and Kw-Cohansey) have limited distribution in basins in southeastern New Jersey (Sugarman et al., 1993), where they contain predominantly inner neritic, deltaic, and tidal flat facies. Descriptions of these facies can be found in Miller, et al. (1994), Miller et al. (Chapter 14, this volume), Miller and Sugarman (1995), and Sugarman and Miller (1997).

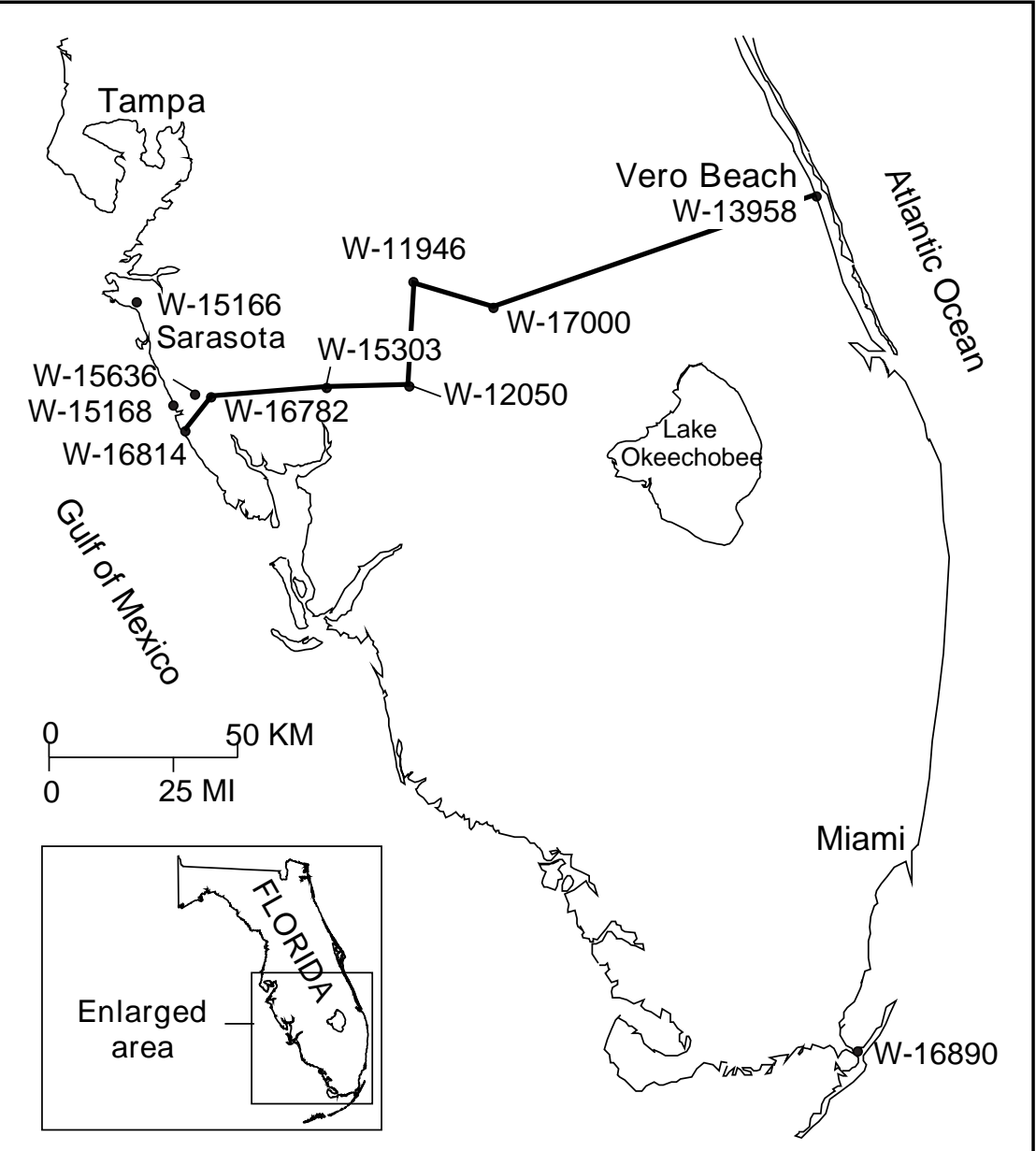

Figure 2. Location of boreholes studied in Florida. Heavy line indicates location of cross section shown in Fig. 3. 
Table 3. ${ }^{87} \mathrm{Sr} /{ }^{86} \mathrm{Sr}$ age regressions from 0 to $7 \mathrm{Ma}$.

\begin{aligned} & \hline $\begin{array}{c}\text { Age } \\ (\mathrm{Ma})\end{array} \multicolumn{1}{c}{$ Equation } \\ & \hline $0-2.5$ Age $(\mathrm{Ma})=15235.09-\left({ }^{87} \mathrm{Sr} /{ }^{86} \mathrm{Sr}\right) \times 21482.28 \\ & 2.5-4.8$ Age $(\mathrm{Ma})=59941.95-\left({ }^{87} \mathrm{Sr} r^{86} \mathrm{Sr}\right) \times 84530.85 \\ & 4.8-7.0$ Age $(\mathrm{Ma})=15640.06-\left({ }^{87} \mathrm{Sr}{ }^{86} \mathrm{Sr}\right) \times 22050.72 \\ &$\hline\end{aligned}

Note: Based on data from Farrell et al. (1995).

\section{New Jersey Oligocene Sequences}

New Jersey Oligocene sequences determined from the Island Beach, Atlantic City, and Cape May boreholes have been identified by Pekar (1995) and Pekar et al. (Chapter 15, this volume). A short synthesis of these Oligocene sequences, termed O1 through O6, is given below. In New Jersey, the Oligocene rests unconformably over the Eocene with a hiatus of at least 1.0 m.y. (33.8-32.7 Ma).

\section{Lowermost Oligocene Sequence 01}

Sequence $\mathrm{O} 1$ is present at Island Beach and Cape May; it may be equivalent with the Mays Landing unit named at the ACGS\#4 borehole by Owens et al. (1988), although it is possible that the latter is a slightly older sequence. Its age is $32.8-32.2 \mathrm{Ma}$, and it is assigned to Zones P18 and NP22 (Pekar and Miller, 1996; Pekar et al., Chapter 15 , this volume).

\section{Lower Oligocene Sequence $\mathrm{O2}$}

Sequence O2 is separated from Sequence O1 by a hiatus of $\sim 1$ m.y. (at Island Beach) to 3 m.y. (at Atlantic City; Pekar et al., Chapter 15 , this volume). Sequence O2 represents less than 1 m.y. (30.8-29.9 $\mathrm{Ma}$ ) and is assigned to Zones P19 and perhaps P20 partim (Pekar and Miller, 1996; Pekar et al., Chapter 15, this volume).

\section{Lower Oligocene Sequence $\mathrm{O3}$}

A hiatus of $\sim 1$ m.y. (29.9-29.0 Ma) separates Sequence O3 from Sequence O2. Sequence O3, with an age of 29.0-28.3 Ma, is only observed at the Atlantic City borehole, where it is equivalent to Zone P21a (Pekar and Miller, 1996; Pekar et al., Chapter 15, this volume).

\section{Lower Upper Oligocene Sequence 04}

Sequence O4 is late Oligocene (27.5-27.0 Ma) and unconformably overlies sequence $\mathrm{O} 3$, from which it is separated by a hiatus of $\sim 1 \mathrm{~m}$.y. The sequence, equivalent to Zone P21b (Pekar et al., Chapter 15 , this volume), is found in the Cape May, Atlantic City, and Island Beach boreholes.

\section{Upper Oligocene Sequences O5/O6}

Sequence $\mathrm{O} 5$ is found only at Atlantic City, where its age is 27.025.6 Ma. It is equivalent to Zone P22. The hiatus between Sequences O5/O4 is below the resolution of Sr-isotope stratigraphy. Sequence O5 is an excellent example of a "New Jersey" sequence in that it coarsens upward from a glauconite sand with outer neritic biofacies to a coarse glauconitic quartz sand with inner neritic biofacies. Sequence O6 (25.1-24.2 Ma), also equivalent to Zone P22, was identified at Atlantic City and Cape May. There is no definite hiatus between Sequences O5 and O6, although a hiatus of 0.5 m.y. is possible. Sequences O5 and O6 may, in fact, be one sequence (Pekar et al., Chapter 15, this volume).

\section{New Jersey Miocene Sequences}

Miocene sequences have been dated with Sr-isotope stratigraphy at the Atlantic City and Cape May boreholes (Table 1), where at least seven, and possibly as many as nine, lower to middle Miocene sequences have been identified.

\section{Lowermost Miocene Sequence Kw0}

The basal Miocene sequence (Kw0), dated as 23.6-23.3 Ma at Cape May, is a glauconite sand. At Atlantic City, three shell beds (>0.5 m thick) with glauconite sand (937-924 ft [285.6-281.6 m]) spanning the Oligocene/Miocene boundary ( $\mathrm{Sr}$ ages of 25.3-21.7 Ma) may represent three truncated sequences (Miller, et al., 1994), including one (23.6-21.4 Ma) that may correlate to Kw0 at Cape May.

\section{Lower Miocene Sequences Kw1a and Kw1b}

The Kw1a sequence, deposited between 21.1 and $20.1 \mathrm{Ma}$, is the most pervasive sequence in the New Jersey subsurface (Sugarman et al., 1993). Shell beds ( 1 m thick) and glauconitic sands mark the base of Kw1a. At Atlantic City, the Kw1a sequence (183 ft thick [56 $\mathrm{m}]$ ) shallows upward, with shelf and prodelta silty clays in the base and delta front sands at the top.

At Atlantic City, the Kw1b sequence is dated as 20.1-19.9 Ma. $\mathrm{Sr}$ isotopes cannot be used to resolve a hiatus between Kwla and $\mathrm{Kw} 1 \mathrm{~b}$ sequences, although a distinct disconformity is indicated by gamma logs, facies shifts, and an irregular surface at the contact (see also Owens et al. [1988], ACGS\#4 borehole; Fig. 1). The section from 850 to $710 \mathrm{ft}(259-216 \mathrm{~m})$ at Cape May appears to be younger (19.3-18.4 Ma) than the Kw lb sequence at Atlantic City; it may represent a thicker upper Kw1b section, or a previously unrecognized sequence $(\mathrm{Kw} 1 \mathrm{c})$.

\section{Upper Lower (Kw2a) and Lower Middle (Kw2b) Miocene Sequences}

A major unconformity (0.5- to 2.0-m.y. hiatus) occurs at the base of Kw2. The overall Kw2 sequence of Sugarman et al. (1993) can be split into a Kw2a (17.8-16.6 Ma) and a Kw2b (16.1-15.6 Ma) sequence separated by a hiatus of $\sim 0.5 \mathrm{~m} . \mathrm{y}$.

\section{Unnamed Middle Middle Miocene Sequence}

At Cape May, there appears to be a middle middle Miocene (previously unnamed) sequence (Kw2c) that is not present at Atlantic City. The sequence is a shelfal quartz sand with Sr-isotopic ages of 15.2-14.2 Ma. If the uppermost sample at $514 \mathrm{ft}(156.7 \mathrm{~m})$ is excluded because of a stratigraphic age inversion, then the sequence is better dated at 14.6-14.2 Ma.

\section{Middle Middle Miocene Kw3 Sequence}

A major unconformity separates the Kw2c and Kw3 sequences. The Kw3 sequence is dated as 13.8-13.4 Ma at Atlantic City.

\section{Upper Middle Miocene Kw-Cohansey Sequence}

The upper middle Miocene Kirkwood-Cohansey sequence is present at Cape May and dated at 12.1-11.5 Ma (see Miller, et al., 1996a, for discussion).

\section{Florida Depositional Styles}

Oligocene and Miocene sedimentary rocks in west-central, peninsular Florida consist of two major lithofacies that differ mainly in their proportions of carbonate and siliciclastic sediment. One lithofacies consists of a series of carbonate beds containing relatively low percentages of siliciclastic and phosphatic minerals. This lithofacies forms most of the lower Oligocene Suwannee Limestone and the Tampa Member of the Arcadia Formation (Hawthorn Group of Scott, 
1988). The second lithofacies consists of cycles of silty claystone (locally phosphatic) or carbonate-cemented quartz sandstone interbedded with carbonate beds (also locally phosphatic). This lithofacies characterizes the upper Oligocene and lower to lower middle Miocene deposits, which include most of the Arcadia Formation of Scott (1988), except the Tampa Member.

The two lithofacies reflect the changing influence of terrigenous sedimentation in the depositional history of the region. The biogenic carbonate and phosphatic deposits were generated within the depositional basins, typically at or near the site of accumulation and burial. Terrigenous sediments provided by south-flowing rivers originating in crystalline rocks and coastal plain beds in Georgia and adjacent states moved southward along both coasts of the Florida peninsula by longshore marine currents (McCartan and Owens, 1991; McCartan et al., 1995b, 1995c; Mallinson and Compton, 1995). During periods of high influx of sand, silt, and clay, the relative proportion of carbonate shell fragments diminished. The main locus of siliciclastic sediment transport and accumulation is now along the east coast, as it was along preexisting east-coast shorelines. The secondary locus is the modern west coast and its precursors (McCartan and Owens, 1991; McCartan et al., 1995a, 1995b). Biogenic carbonate shoals occupy much of the area between the main siliciclastic pathways, and carbonate debris from the shoals interfingers laterally with siliciclastic debris along the east and west margins of the Florida Peninsula.

\section{Florida Sequences}

The sequences developed in this study are from a transect of boreholes across the Florida Peninsula (Fig. 2). We illustrate the lithologies and sequences from seven of these boreholes (Figs. 3A, 3B). The lithostratigraphic units were published by Scott (1988) and slightly revised in McCartan et al. (1995c). We identify Oligocene Sequences FO1 through FO3 and Miocene Sequences FM1 through FM5 based on integration of the lithostratigraphy and Sr-isotopic data (Figs. 3, 4, 5; Table 2).

\section{Early Oligocene Sequence FO1}

Sequence FO1, contained within the "Suwannee" Limestone, unconformably overlies the upper Eocene Ocala Limestone. Limited Sr-isotopic age estimates from upper Eocene strata $(\mathrm{W}-15303=34.2$ $\mathrm{Ma}$; $\mathrm{W}-11946$ and $\mathrm{W}-17000=35.7 \mathrm{Ma}$ ) provide a tentative age range of 35.7-34.2 Ma (Fig. 4; Table 2) for the uppermost Eocene sequence in Florida. In Core W-17000, an unconformity with a maximum hiatus of 2.7 m.y. (35.7-33.6 Ma) is present between the upper Eocene sequence and lower Oligocene Sequence FO1. W-15303 provides the best set of $\mathrm{Sr}$-isotopic ages for this sequence, which are between 32.6 and 31.7 Ma. The overall ages for Sequence FO1 are 33.3-31.7 Ma (Table 2). In general, this sequence is a relatively pure limestone with low-amplitude, low-frequency spikes on the gamma logs (Fig. 3).

\section{Upper Lower Oligocene Sequence FO2}

The Sr-isotopic age range for Sequence FO2 is 30.5-28.4 Ma (Fig. 4). It is often correlated with strata assigned to the Nocatee Member of the Arcadia Formation, except along the west coast, where it is correlated with the lower undivided part of the Arcadia Formation. The hiatus separating Sequences FO2 and FO1 is significant. For example, in Borehole W-15303 (Table 2), a maximum hiatus of $2.6 \mathrm{~m}$.y. is associated with a sequence boundary between 528.5 $\mathrm{ft}(161.1 \mathrm{~m} ; 31.7 \mathrm{Ma})$ and $433 \mathrm{ft}(132 \mathrm{~m} ; 29.1 \mathrm{Ma})$. The hiatus may be as short as $1.3 \mathrm{~m}$.y. because of diagenetic alteration of the $433-\mathrm{ft}$ sample. Samples from Sequence FO2 in Borehole W-16814 have a Sr-isotopic age range of 30.1-28.7 Ma (Table 2).

\section{Lower Upper Oligocene Sequence FO2b}

Three data points from separate boreholes suggest the possibility of another sequence in the early late Oligocene of Florida with a Sr- isotopic age range of 28.0-27.5 Ma (Fig. 4). A sample from $230 \mathrm{ft}$ $(70.1 \mathrm{~m})$ in Corehole W-15303 yielded a Sr-isotopic age of 27.9 Ma. Another sample from Corehole W-11669 at $369 \mathrm{ft}(112.5 \mathrm{~m})$ had a Sr-isotopic age of $27.5 \mathrm{Ma}$, whereas the 355.5 -ft sample $(108.4 \mathrm{~m})$ from W-12050 had a Sr-isotopic age of 28.0 Ma (Table 2). Because the possible hiatus of 0.4 m.y. between this sequence and the FO2 sequence is below the resolution for Sr-isotope stratigraphy, we consider Sequence FO2b as the upper part of sequence FO2.

\section{Upper Oligocene Sequence FO3}

Sequence FO3 has a Sr-isotopic age range of 26.3-25.3 Ma (Fig. 4). A reliable series of $\mathrm{Sr}$-isotopic age estimates for this sequence was derived from Borehole W-16782, where four samples ranged from 26.2 to $25.5 \mathrm{Ma}$ (Table 2). A 1.2-m.y. hiatus separates the FO3 and FO2b sequences. Sequences FO2, FO2b, and FO3 consist of a mixture of siliciclastic, phosphatic, and carbonate deposits with higher amplitude, higher frequency spikes on the gamma logs (Fig. 3).

\section{Lower Miocene Sequence FM1}

A major hiatus of $\sim 2$ m.y. (25.5-22.9 Ma) separates Oligocene Sequence FO3 from Miocene Sequence FM1 in south Florida. Sequence FM1 has a Sr-isotopic age range of 22.9-20.9 Ma (Fig. 5).

\section{Upper Lower Miocene Sequence FM2}

Miocene sequence FM2 has a Sr-isotopic age range of 20.8-18.2 Ma. The duration of the hiatus at the FM2/FM1 sequence contact could not be resolved in this study. FM2 is well dated using Srisotopes in the W-12050 borehole at 20.8-18.6 Ma (Table 2). It is possible that an unconformity exists between the $124-\mathrm{ft}(37.8 \mathrm{~m} ; 18.6$ $\mathrm{Ma}$ ) and 160 -ft samples $(48.8 \mathrm{~m}$; $19.3 \mathrm{Ma})$. We were unable to locate the lithologic contact that corresponds to the FM2/FM1 sequence contact; however, additional cores might recover it. In northeast Florida, Mallinson and Compton (1995) identified two depositional sequences with maximum sea-level fluctuations at 20.5 and 18.7 Ma.

\section{Upper Lower Miocene Sequence FM3}

Sequence FM3 has a Sr-isotopic age range from 17.5 to $16.5 \mathrm{Ma}$ (Fig. 5). An excellent section of this sequence from Borehole W-16505 yielded Sr-isotopic ages of 17.8-16.8 Ma.

\section{Lower Middle Miocene Sequence FM4}

Sequence FM4 has an age range from 16.2 to $15.7 \mathrm{Ma}$ (Fig. 5). The hiatus between FM3 and FM4 ( 0.3 m.y.) is below the resolution of Sr-isotope stratigraphy, but is present in Borehole W-16505 between 570.0 and $595 \mathrm{ft}$ (173.7 and $181.4 \mathrm{~m})$.

\section{Upper Middle to Lower Upper Miocene Sequence FM5}

Sequence FM5 is tentatively identified only in Boreholes W-15286 and $\mathrm{W}-16890$ in the southern peninsula. Sr-isotopic age estimates are 12.0-11.3 Ma (Fig. 5).

\section{DISCUSSION \\ Correlation of Coastal Plain Sequences with Global Sea-Level Proxies}

The age of Oligocene and Miocene sequence boundaries determined in cores from New Jersey and Florida show excellent correlation with deep-sea $\delta^{18} \mathrm{O}$ increases, which are inferred glacioeustatic lowerings (Figs. 4, 5). Lower Oligocene sequence boundaries in Alabama also appear to correlate with $\delta^{18} \mathrm{O}$ increases (Miller et al., 


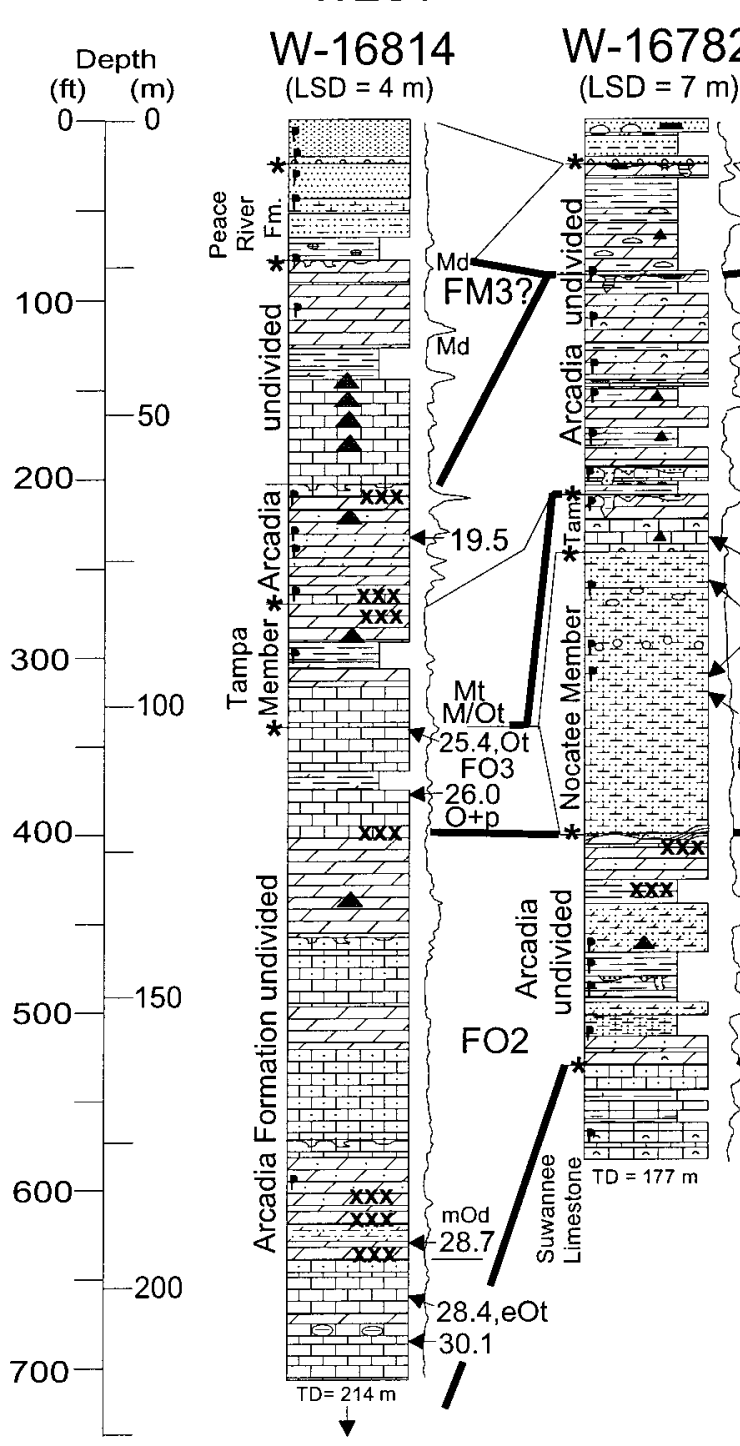

W-15303

$(\mathrm{LSD}=7 \mathrm{~m})$

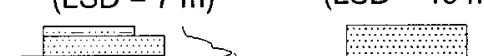

W-11946

$(\mathrm{LSD}=20.5 \mathrm{~m}$ )

$W-17000$

EAST $\longrightarrow$

W-13958

Holocene
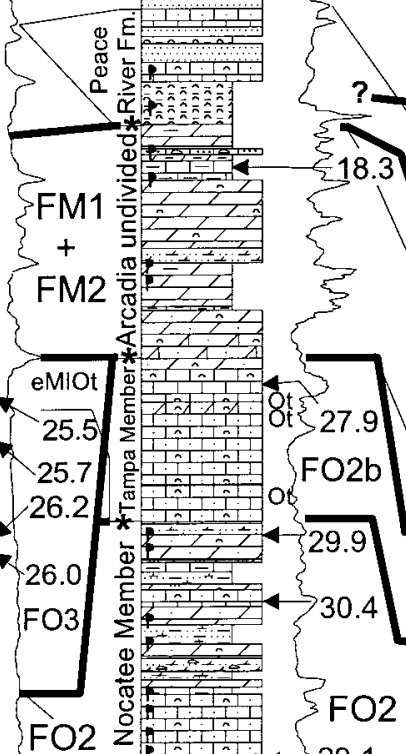

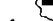
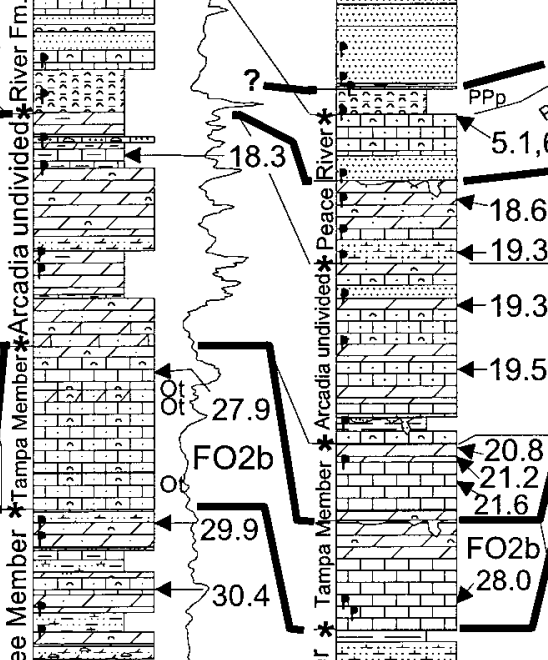
* $*$ to
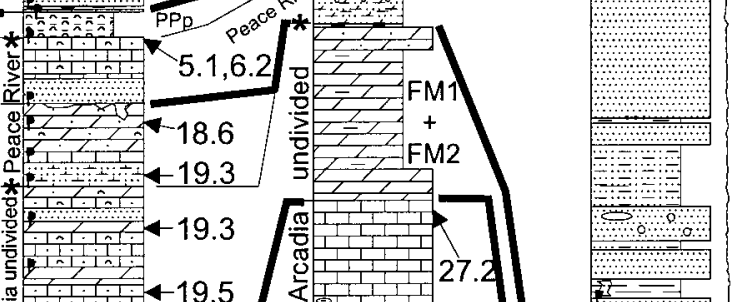

$4-19.3$
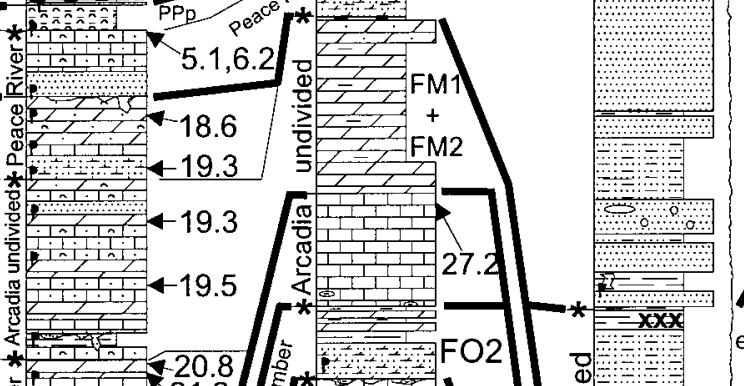

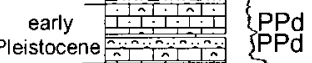

early

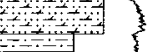
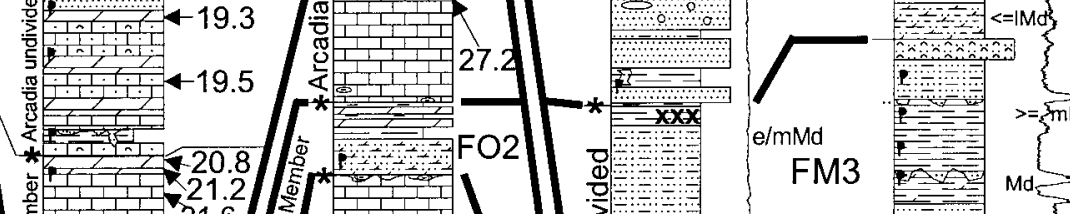

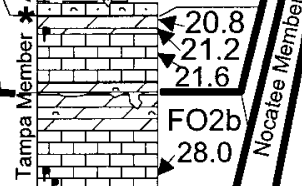

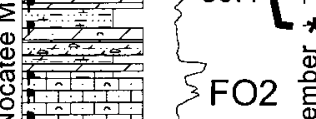

站1
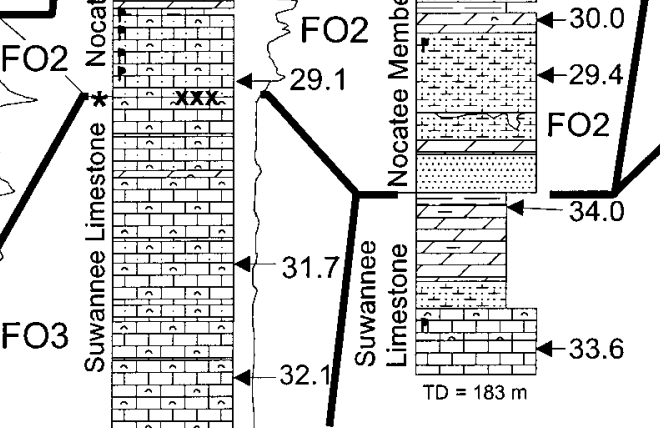

30.0

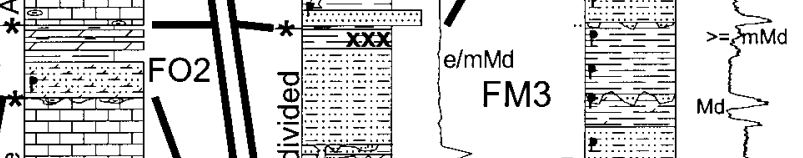

FM3
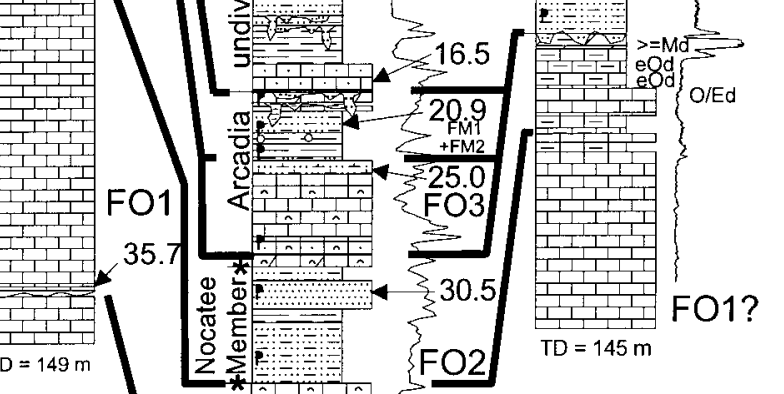

$\mathrm{TD}=437 \mathrm{~m}$

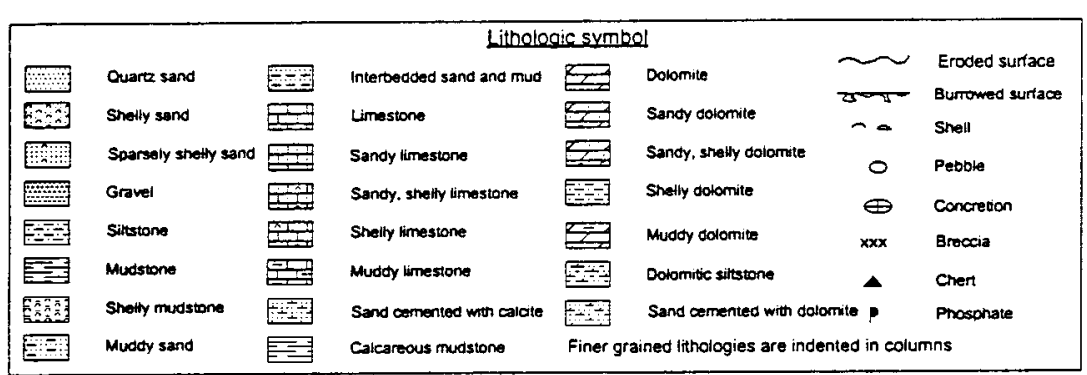

\begin{tabular}{|c|c|}
\hline \multicolumn{2}{|c|}{ 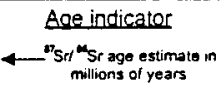 } \\
\hline & Purscosonse Procense \\
\hline M & Muccene \\
\hline & 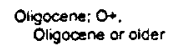 \\
\hline E & Eocene \\
\hline I & Late \\
\hline $\mathrm{m}$ & Middre \\
\hline e & Earty \\
\hline 1 & Tummella \\
\hline & Dinolagellate \\
\hline & Younger tran \\
\hline & Oider than \\
\hline
\end{tabular}

Figure 3. East-west cross section across the central Florida peninsula showing well lithologies, gamma-ray geophysical logs (where available), sequence terminology, and stratigraphic nomenclature. LSD = land surface datum. 


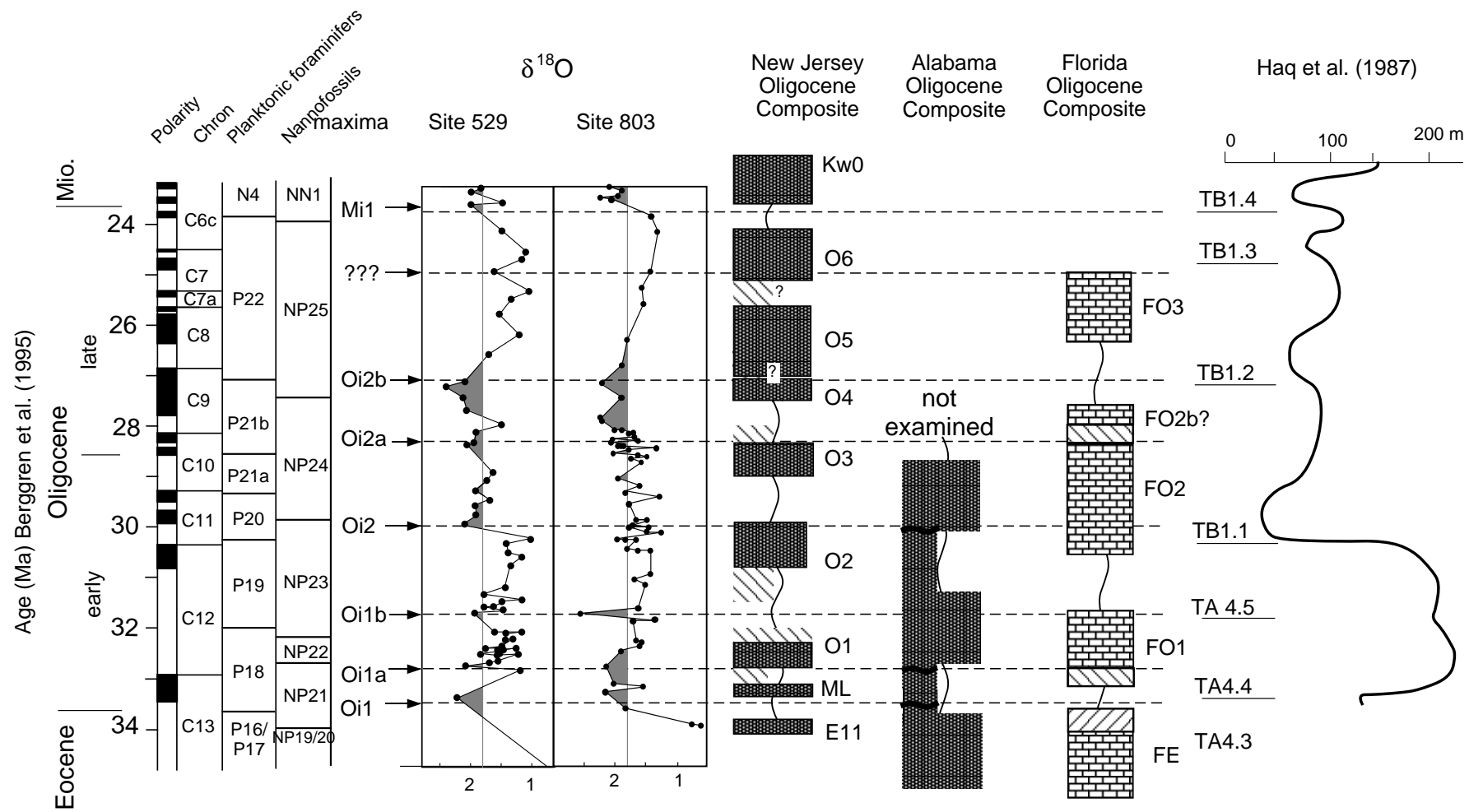

Figure 4. Comparison of New Jersey, Florida, and Alabama Oligocene sequences and the deep-sea $\delta^{18} \mathrm{O}$ record and the Haq et al. (1987) inferred eustatic record. Ages are based on the GPTS of Berggren et al. (1995). Isotope maxima are from Miller et al. (1991b) and Pekar et al. (Chapter 15, this volume). Alabama data from Miller et al. (1993). Thinner boxes in the Alabama column are areas of uncertainty.

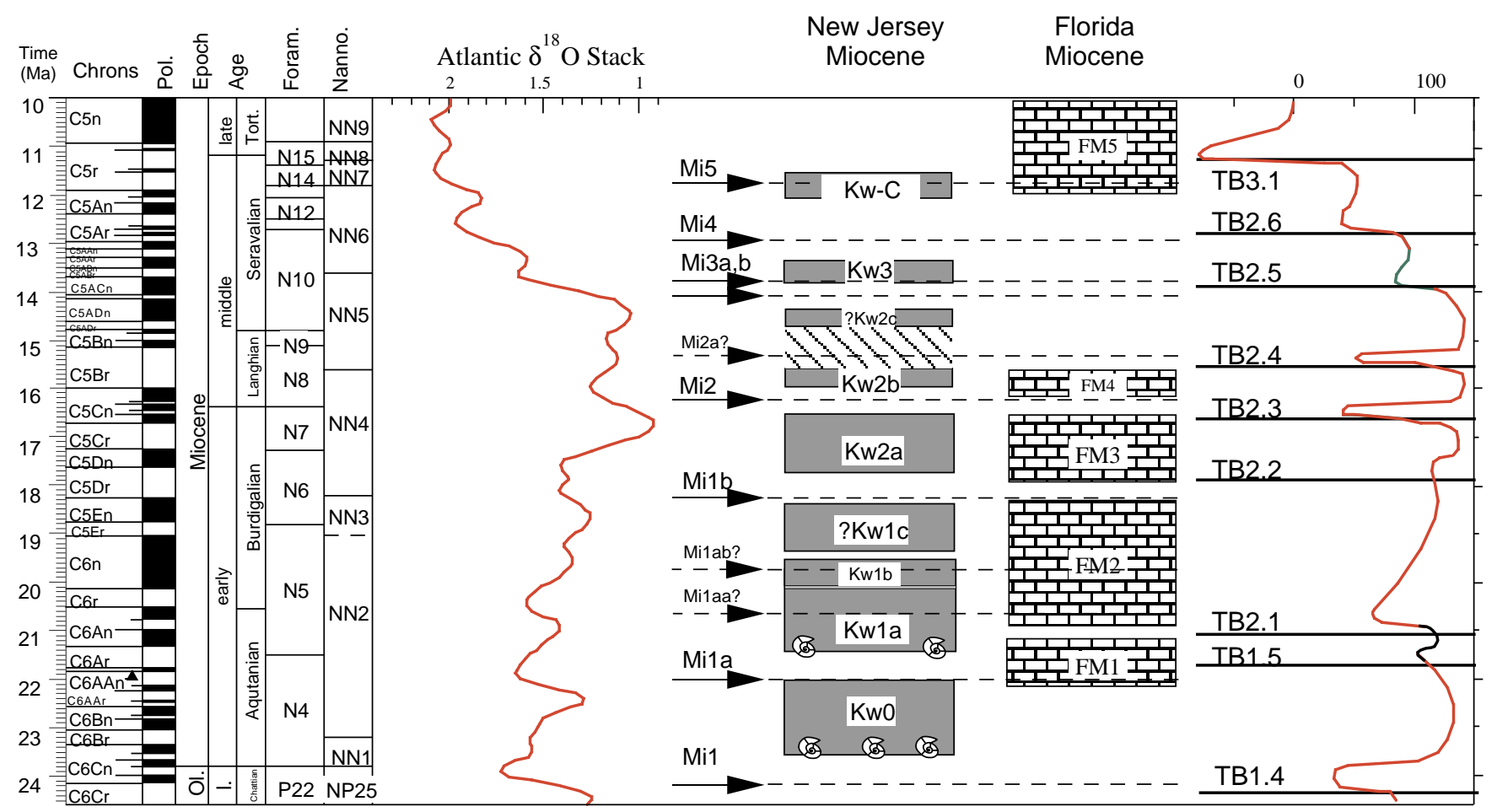

Figure 5. Comparison of New Jersey and Florida Miocene sequences with the deep-sea $\delta^{18} \mathrm{O}$ record (Miller et al., 1991b, 1996b) and the Haq et al. (1987) inferred eustatic record. 
1993; Fig. 4). Assuming that these correlations are valid (see below for discussion of uncertainties in correlations), this is strong confirmation that global sea-level change is a primary control on the timing of Oligocene sequence boundaries for the coastal plain sections studied here.

Hiatuses separate Eocene sequences from the oldest Oligocene sequences in New Jersey and Florida, and there is a probable hiatus in Alabama (Fig. 4). These earliest Oligocene hiatuses correlate with the Oil and Oila $\delta^{18} \mathrm{O}$ increases (33.5 and $32.8 \mathrm{Ma}$ ) and with the TA4.4 sequence boundary of Haq et al. (1987; Fig. 4). The Oil event is a major earliest Oligocene increase that represents at least 30-50 $\mathrm{m}$ of glacioeustatic lowering (Miller et al., 1991b).

The Oila and Oilb $\delta^{18} \mathrm{O}$ increases are smaller amplitude $(<0.5 \%$ ) increases identified in higher resolution deep-sea records (Pekar et al., Chapter 15 , this volume), and their global significance is unknown. Nevertheless, we assume that they represent probable sealevel lowerings of $\sim 20-30 \mathrm{~m}$, and there is a reasonable correlation of events in New Jersey, Florida, and Alabama with these increases. The $\mathrm{O} 1$ sequence in New Jersey and FO1 sequence in Florida are bracketed by the Oi1/Oila (33.5/32.8 Ma) and Oilb (31.7 Ma) $\delta^{18} \mathrm{O}$ increases. A possible lowermost Oligocene sequence in New Jersey at the ACGS\#4 borehole (Owens et al., 1988) may be bracketed by the Oil and Oila increases (ML in Fig. 4). Although both the Oila and Oilb $\delta^{18} \mathrm{O}$ increases apparently correlate with no discernible hiatuses in Alabama, the former correlates with a possible sequence boundary at the top of the Forest Hill/Red Bluff Formations (top of Chronozone $\mathrm{C} 13 \mathrm{n}$ ) and the latter with the base of the Glendon Formation (Miller et al., 1993).

The major Oi2 (30.3 Ma) $\delta^{18} \mathrm{O}$ increase (Fig. 4) correlates (1) reasonably well with a hiatus in New Jersey, (2) moderately well with a hiatus in Florida between the FO2 and FO1 sequences, and (3) very well with a major sequence boundary at the base of the Chickasawhay Formation in Alabama (Miller et al., 1993). The O2 sequence in New Jersey correlates with the TA4.5 cycle of Haq et al. (1987).

The Oi2 (30.3 Ma) and Oi2a (28.1 Ma) $\delta^{18} \mathrm{O}$ increases are almost identical in age to the FO2 sequence boundaries (Fig. 4). The O3 sequence in New Jersey represents a much shorter sequence that was deposited between $\delta^{18} \mathrm{O}$ increases. The upper surface of the $\mathrm{O} 4 \mathrm{New}$ Jersey sequence correlates well with the Oi2a/Oi2b (27.0 Ma) zonal boundary. A possible sequence of short duration may also be present in Florida during the time interval between the Oi2a and Oi2b $\delta^{18} \mathrm{O}$ increases.

The uppermost Oligocene 05/O6 sequences are bracketed by the Oi2b and Mi1 $\delta^{18} \mathrm{O}$ increases, with the upper surface of the $\mathrm{O} 6 \mathrm{se}$ quence being coeval with the Mi1 increase (23.8 Ma). The O5/O6 sequence boundary may correlate with a minor, unnamed $\delta^{18} \mathrm{O}$ increase (Fig. 4; Pekar et al., Chapter 15, this volume). The FO3 sequence in Florida may correlate with the New Jersey O5 sequence. The O5 and O6 sequences correlate well with the TB1.2 and TB1.3 cycles of Haq et al. (1987). The FO3 sequence correlates with their TB1.2 sequence.

Miller and Sugarman (1995) and Miller, et al. (1996a) documented correlation between New Jersey Miocene onshore sequences, $\delta^{18} \mathrm{O}$ increases, and Haq et al. (1987) sequences using the Berggren et al. (1985) time scale. Using the Berggren et al. (1995) time scale improves the comparisons further. For example, the Mi1, Mila, Milb, $\mathrm{Mi} 2, \mathrm{Mi} 3 \mathrm{a} / \mathrm{b}$, and Mi4 $\delta^{18} \mathrm{O}$ increases correlate with hiatuses associated with the New Jersey sequence boundaries Kw0, Kw1a, Kw2a, $\mathrm{Kw} 2 \mathrm{~b}, \mathrm{Kw} 3$, and $\mathrm{Kw}-\mathrm{Cohansey,} \mathrm{respectively,} \mathrm{and} \mathrm{the} \mathrm{Haq} \mathrm{et} \mathrm{al.}$ (1987) Sequences TB1.4, TB1.5/2.1, TB2.2, TB2.3, TB2.5, and TB2.6, respectively (Fig. 5). Smaller $\delta^{18} \mathrm{O}$ increases not previously identified (Milaa, Milab, Mi2a on Fig. 5) may correlate with the remaining $\mathrm{Kw} 1 \mathrm{~b}$, Kw1c, and $\mathrm{Kw} 2 \mathrm{c}$ sequence boundaries, although the significance of these increases and higher order sequences is uncertain.

The New Jersey onshore sequences also correlate reasonably well with the Florida Miocene sequences described here and with the northeastern Florida sequences described by Mallinson and Compton
(1995). The bases of the FM2, FM3, and FM4 sequences correlate with the bases of Kw1a, Kw2a, and Kw2b sequences, respectively (Fig. 5).

There are still uncertainties in the correlations presented here. First, the significance of the higher order sequences (e.g., Kw1b, $\mathrm{Kw} 1 \mathrm{c}, \mathrm{Kw} 2 \mathrm{c}$ ) is not certain. Second, correlation with several of the Haq et al. (1987) cycles still remains equivocal. For example, Miller et al. (1996b) correlated the TB2.4 Haq et al. (1987) cycle with the Mi3a and 3b oxygen-isotope events, a correlation that we still prefer; however, we show that it may be possible to correlate TB2.4 with an older, albeit smaller scale, oxygen-isotopic event ("Mi2a"). Third, Sr-isotopic stratigraphy has age resolution of $\pm 0.6-0.4 \mathrm{~m}$.y. for the early Miocene and $\pm 1.2-0.8$ m.y for the middle Miocene at the $95 \%$ confidence interval using 1 and 3 analyses per level, respectively (Oslick et al., 1994).

To evaluate the validity of $\mathrm{Sr}$-isotopic correlations of sequence boundaries and $\delta^{18} \mathrm{O}$ increases, we tied sequence boundaries at Cape May and Atlantic City directly to the benthic foraminiferal $\delta^{18} \mathrm{O}$ record at ODP Site 608 (Fig. 6; Miller et al., 1991a). We did this by projecting New Jersey $\mathrm{Sr}$-isotopic values onto a linear fit of $\mathrm{Sr}$ vs. depth at Site 608 (Fig. 6), circumventing any uncertainties in the $\mathrm{Sr}$ age calibrations. With the exception of the Kw2b-Mi2 correlation, all of the other correlations are actually improved using this method (Fig. 6). This also suggests that some of the slight ( $<0.5$ m.y.) mismatches between the smoothed $\delta^{18} \mathrm{O}$ records and sequences (Figs. 4, 5) results from problems in stacking and smoothing the stable isotopic records from three sites. We conclude that our correlations of sequence boundaries with $\delta^{18} \mathrm{O}$ increases are valid and that glacioeustasy is responsible for forming these unconformities.

\section{Sedimentation and Tectonics}

Siliciclastic sediments in the New Jersey Margin record the dynamics between sediment supply, subsidence, and eustasy. The typical New Jersey sequence (Sugarman et al., 1993; 1995) is an unconformity-bounded, shoaling-upward, sedimentary column whose architecture offers some clues to the dynamics of sea level, subsidence, and sediment supply. The lowermost parts of sequences consist of beds of glauconite sand or quartzose glauconite sand $(\sim 3-6 \mathrm{~m}$ thick $)$ deposited in middle to outer shelf environments. These beds accumulated at a relatively low rate of 1-5 m/m.y. (Sugarman et al., 1995; Miller and Sugarman, 1995). These low sedimentation rates suggest sediment supply was limited. The clay-silts and quartz sands found in the middle to upper part of sequences record a progradational phase in which sediment supply was more plentiful in shallower water environments (e.g., inner shelf, delta front). Sedimentation rates in these Highstand Systems Tract deposits were relatively rapid (25-100 m/m.y.), with the majority of the sediment deposited more quickly when compared with the Transgressive Systems Tract. In order for the bulk of the sequence to be deposited in a relatively short amount of time, some combination of increased sediment supply (tectonics?; proximity to the depocenter?) coupled with increased subsidence seems necessary to allow accommodation in shallow-water depths $(<30 \mathrm{~m})$.

Although global sea level has been shown to have a significant influence on coastal plain sequences (Figs. 4, 5), comparisons of sequences within the same depositional basin and between basins have been shown to vary significantly (e.g., Pekar et al., Chapter 15, this volume; Miller and Sugarman, 1995). In a comparison of New Jersey and Maryland Miocene sections from the Salisbury Embayment, Miller and Sugarman (1995) demonstrated that most of the lower Miocene present in New Jersey is missing in outcrop and the subsurface of Maryland. In contrast, the upper Miocene to Pliocene is largely nonmarine and thin in New Jersey, but is thicker and largely marine in Maryland (Gibson, 1983). These differences are likely the result of tectonics. One possible mechanism that could explain the distribution of sequences is progressive downwarping of the Salisbury Embayment to the south (Owens et al., Chapter 2, this volume). This would 


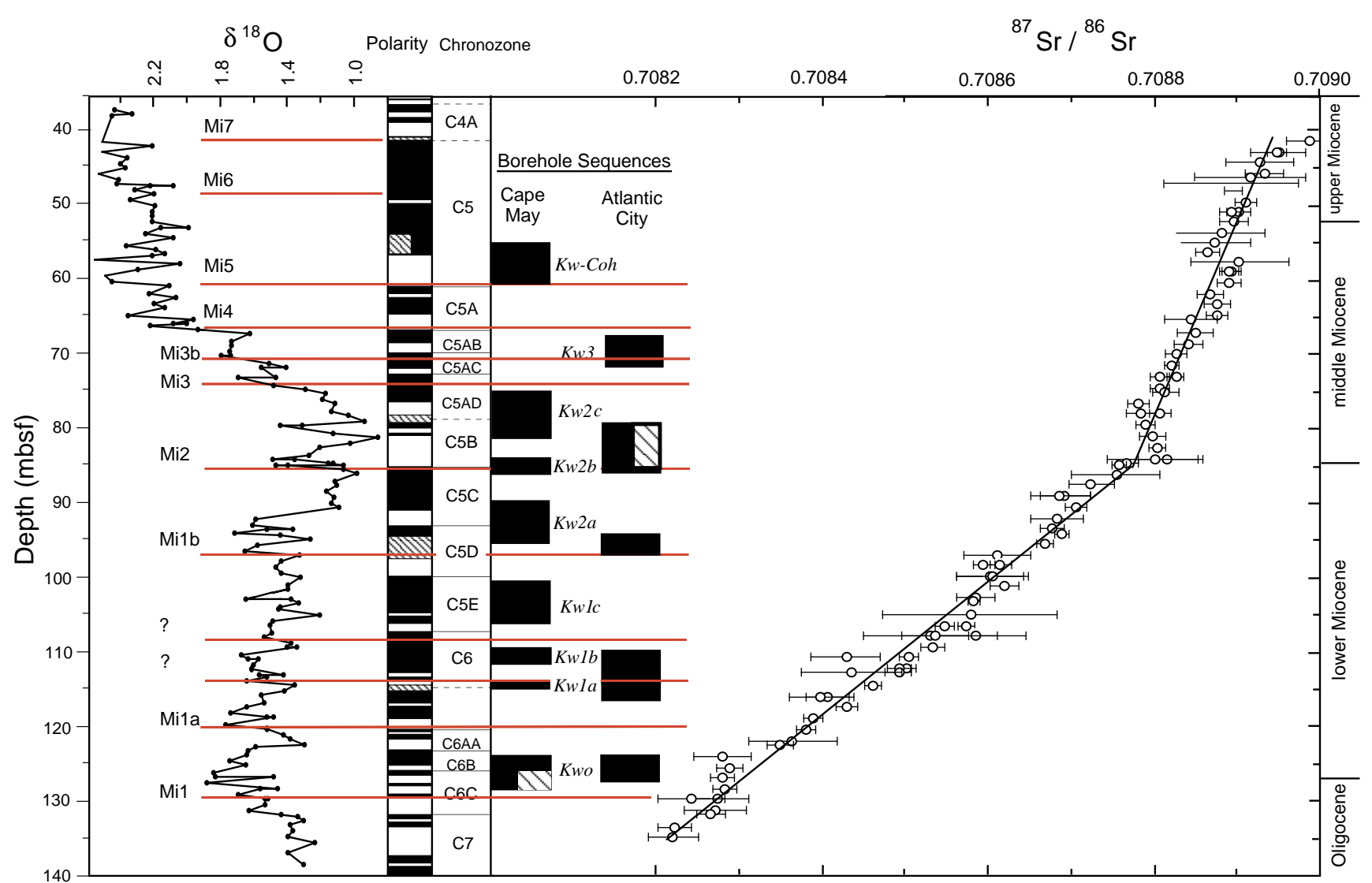

Figure 6. Projection of Leg 150X Miocene Sr-isotopic values on the Sr- and oxygen-isotopic and magnetostratigraphic record at Site 747 (Oslick et al., 1994$).$ Two linear regressions were fit through the Site $747 \mathrm{Sr}$-isotopic data, and Sr-isotopic values for the Leg 150X sequences (Table 1) were projected from their corresponding values on the regression to the equivalent depths. Sequences projected into the Site 747 depths are indicated as black boxes; equivalent hiatuses are indicated with open intervals. Such projections allow direct comparison of the sequence with the oxygen-isotopic proxy for glacioeustasy, independent of age models and time scales.

have allowed thicker lower Miocene accumulations in New Jersey than in Maryland, where a possible arch prevented sediment accumulation (Owens et al., 1988; Owens et al., Chapter 2, this volume). As the basin subsided to the south, thicker marine deposits would have been preserved in the southern Salisbury Embayment (Maryland) compared with thinner marginal to nonmarine deposits in New Jersey in the upper middle and upper Miocene. Other possible explanations for the absence of lower Miocene strata in Maryland include faulting of crustal blocks (Brown et al., 1972), local flexural subsidence (Pazzaglia and Gardner, 1994), or differential subsidence caused by sediment loading (Miller and Sugarman, 1995).

Regional differences among sequences in Florida also may reflect local nondeposition caused by tectonic emergence or significant postdepositional erosion. For example, a significant break that occurred across the Oligocene/Miocene boundary (about 23.7 Ma) in Florida (Table 4; e.g., between Sequences FO3 and FM1 in central Florida; Figs. 4, 5) can be unequivocally attributed to the Mi1 glacioeustatic fall (Miller et al., 1991b); however, the long hiatus associated with this boundary (e.g., 3 m.y. in central Florida; Figs. 4, 5) may reflect regional tectonic accentuation. The distribution of other Floridian Oligocene to Miocene strata also may reflect tectonic effects on the following:

1. In the northwest, the entire upper Oligocene and most of the middle and upper Miocene appear to be missing. Mallinson et al. (1994) believed that the northeast corner of Florida was emergent during most of the Oligocene, and emergence may also account for the general absence of upper Oligocene strata in the northwest.

2. In the northeast, the lower Oligocene and most of the upper Oligocene are missing, and the middle and upper Miocene are well represented (Mallinson et al., 1994; Table 4).

3 . In the central part of the peninsula, most of the middle Miocene is not represented. This region was emergent during the middle to early late Miocene ( $16 \mathrm{Ma}$ to about 6 or $5 \mathrm{Ma}$ ), judging from biostratigraphic data, including land and estuarine vertebrate paleogeography (Webb et al., 1981; Webb and Hulbert, 1986; Hulbert, 1987), and the absence of marine deposits (Fig. 4).

Changes in sediment provenance and supply also contribute to sequence differences within and between basins. Starting in the early Oligocene, siliciclastic and phosphatic deposition gradually increased as carbonate deposition declined in northern and central Florida. Today, carbonate deposits accumulate only in the Florida Keys and in Florida Bay. Complicating the basic interplay between carbonate, siliciclastic, and phosphatic sedimentation is the effect of locally subsiding basins and uplifting arches (Owens et al., 1988; Owens et al., Chapter 2, this volume), epeirogenic uplift (Opdyke et al., 1984), and limestone dissolution that may cause isostatic rebounding (Opdyke et al., 1984). Despite the importance of changes in sediment provenance and supply and tectonics on deposition in Florida, we note that the similar timing of sequence boundaries between New Jersey and Florida and their close association with $\delta^{18} \mathrm{O}$ increases (Fig. 
Table 4. ${ }^{87} \mathrm{Sr} /{ }^{86} \mathrm{Sr}$ ages estimates of Oligocene and Miocene sea-level highstands in Florida.

\begin{tabular}{|c|c|c|c|c|c|c|}
\hline $\begin{array}{l}\text { Stratigraphic age } \\
\text { (Ma) }\end{array}$ & $\begin{array}{l}\text { Northcentral and } \\
\text { northwestern }(\mathrm{S})^{\mathrm{a}}\end{array}$ & $\begin{array}{l}\text { Northeastern } \\
(\mathrm{P} \& \mathrm{D})^{\mathrm{b} *}\end{array}$ & $\begin{array}{l}\text { Northeastern } \\
(P \& D)^{b \dagger}\end{array}$ & $\begin{array}{l}\text { Central peninsula } \\
(\mathrm{S})^{\mathrm{c}}\end{array}$ & $\begin{array}{l}\text { Central peninsula } \\
(\mathrm{S})^{\mathrm{a}}\end{array}$ & $\begin{array}{l}\text { Southern peninsula } \\
(\mathrm{S})^{\mathrm{c}}\end{array}$ \\
\hline $\begin{array}{l}\text { middle middle to } \\
\text { late Miocene }\end{array}$ & $12.1,12.2$ & $\begin{array}{c}6-8 \\
9.1-10.9,12.4\end{array}$ & $\begin{array}{c}7.7 ? \\
8.8-13.6 \\
14.8-14.9\end{array}$ & & & $\begin{array}{c}7.2 ? \\
9.3-11.7 \\
13.7,14.5\end{array}$ \\
\hline $\begin{array}{l}\text { late early to early } \\
\text { middle Miocene }\end{array}$ & 17.5 & $13.2-16.9$ & $15.6-17.3$ & $16.7-17.3$ & & $16.0-17.1$ \\
\hline early Miocene & $\begin{array}{l}18.5,18.7 \\
19.2-20.5\end{array}$ & $\begin{array}{l}17.9-19.2 \\
20.0-21.3\end{array}$ & $\begin{array}{l}17.9-19.3 \\
20.0-21.2 \\
20.6-21.5\end{array}$ & $\begin{array}{r}18.6-19.8 \\
21-21.9\end{array}$ & & $\begin{array}{l}17.7-18.7 \\
19.4-19.9\end{array}$ \\
\hline late Oligocene & $24.4-24.7$ & $24.2-25.9$ & $24.7-26.7$ & $25.3-28$ & $\begin{array}{l}25.3-25.6 \\
28.6-32.1\end{array}$ & $25.7-26.4$ \\
\hline early Oligocene & $33.3-35.5$ & & & $33.3-35.8$ & 34.1 & \\
\hline
\end{tabular}

Notes: $\mathrm{S}=$ shallow-water carbonate shells; P\&D = dolomite and phosphorite grains and crusts. ${ }^{\mathrm{a}}=$ Jones et al., 1993 ; ${ }^{\mathrm{b}}=\mathrm{Mallinson}$ et al., 1994 ; Mallinson and Compton, 1995 $\left(0.708830,0.708629\right.$, and 0.708317 were omitted to emphasize gaps in age estimates); ${ }^{*}=$ calculated using the regression equation of Hodell et al., $1991 ;{ }^{\dagger}=$ calculated using the regression equation of Oslick et al., 1994; ${ }^{\mathrm{c}}=$ Wingard et al., 1994, values only; McCartan, Weedman, et al., 1995.

4) demonstrates that glacioeustasy is a primary control on deposition in these regions.

\section{CONCLUSIONS}

1. Oligocene to lower middle Miocene siliciclastic sequences in New Jersey correlate well with carbonate and mixed carbonatesiliciclastic sequences in central Florida and with lower Oligocene mixed carbonate-siliciclastic sequences in Alabama.

2. There is an excellent correlation between Oligocene to lower middle Miocene sequence boundaries in New Jersey and Florida, lower Oligocene sequences in Alabama, and deep-sea $\delta^{18} \mathrm{O}$ increases, which are inferred glacioeustatic lowerings. These correlations indicate that global sea-level change was a primary control on the timing of Oligocene to Miocene "Icehouse World" sequence boundaries for the Atlantic Coastal Plain.

3. Although Oligocene to Miocene sequences generally correlate throughout the Atlantic Coastal Plain, there are differences among locations. Regional differences are evident in the better preservation of upper lower Oligocene sequences in Florida and Alabama, the absence of the uppermost Oligocene, lowermost Miocene, and upper middle Miocene sequences in Flori$\mathrm{da}$, and the absence of the lowermost Miocene sequence in Maryland. The timing of sequence boundaries is better established in the New Jersey Miocene because of more detailed Srisotopic age estimates from shell beds. Poor correlation exists after the early middle Miocene (post $\sim 15 \mathrm{Ma}$ ) between New Jersey and Florida because the majority of the middle Miocene is missing from central Florida. The early late Miocene is probably represented in New Jersey, although correlation of Sr isotopes to the late Miocene of Florida is not possible, because the majority of upper Miocene strata in New Jersey are nonmarine and contain unsuitable material for $\mathrm{Sr}$-isotope stratigraphy.

\section{ACKNOWLEDGMENTS}

This research was supported by National Science Foundation Grants EAR92-18210 and EAR94-17108 to K. Miller. New Jersey cores were obtained by the New Jersey Coastal Plain Drilling Project, supported by the Continental Dynamics and Ocean Drilling Programs. We thank the Florida Geological Survey for access to core material; Tom Scott (FGS) for discussions on stratigraphy with McCartan, G. Wingard, and S. Weedman on the use of Sr-isotope data from selected Oligocene cores; J. Wright for assistance with oxygen- isotope records; and D. Jones and D. Mallinson for reviews. LamontDoherty Earth Observatory contribution 5686.

\section{REFERENCES}

Abbott, W.H., 1978. Correlation and zonation of Miocene strata along the Atlantic margin of North America using diatoms and silicoflagellates. Mar. Micropaleontol., 3:15-34.

Andrews, G.W., 1988. A revised marine diatom zonation for Miocene strata of the southeastern United States. Geol. Surv. Prof. Pap. U.S., 1481:1-29.

Berggren, W.A., Kent, D.V., Flynn, J.J., and van Couvering, J.A., 1985. Cenozoic geochronology. Geol. Soc. Am. Bull., 96:1407-1418.

Berggren, W.A., Kent, D.V., Swisher, C.C., III, and Aubry, M.-P., 1995. A revised Cenozoic geochronology and chronostratigraphy. In Berggren, W.A., Kent, D.V., Aubry, M.-P., and Hardenbol, J. (Eds.), Geochronology, Time Scales and Global Stratigraphic Correlation. Spec. Publ.Soc. Econ. Paleontol. Mineral., 54:129-212.

Brown, P.M., Miller, J.A., and Swain, F.M., 1972. Structural and stratigraphic framework, and spatial distribution of permeability of the Atlantic Coastal Plain, North Carolina to New York. Geol. Surv. Prof. Pap. U.S., 796:1-79.

Cande, S.C., and Kent, D.V., 1992. A new geomagnetic polarity time scale for the Late Cretaceous and Cenozoic. J. Geophys. Res., 97:13,91713,951 .

Farrell, J.W., Clemens, S.C., and Gromet, L.P., 1995. Improved chronostratigraphic reference curve of late Neogene seawater ${ }^{87} \mathrm{Sr} /{ }^{86} \mathrm{Sr}$. Geology, 23:403-406.

Gibson, T.G., 1983. Stratigraphy of Miocene through lower Pleistocene strata of the United States central Atlantic Coastal Plain. In Ray, C.E. (Ed.), Geology and Paleontology of the Lee Creek mine, North Carolina, I. Smithson. Contrib. Paleobiol., 53:35-80.

Haq, B.U., Hardenbol, J., and Vail, P.R., 1987. Chronology of fluctuating sea levels since the Triassic. Science, 235:1156-1167.

Hart, S.R., and Brooks, C., 1974. Clinopyroxene-matrix partitioning of K, $\mathrm{Rb}, \mathrm{Cs}$, and Ba. Geochim. Cosmochim. Acta, 38:1799-1806.

Hodell, D.A., Mueller, P.S., and Garrido, J.R., 1991. Variations in the strontium isotope composition of seawater during the Neogene. Geology, 19:24-27.

Hulbert R.C., Jr., 1987. A new Cormohipparion (Mammalia, Equidae) from the Pliocene (Latest Hemphillian and Blancan) of Florida. J. Vert. Paleontol., 7:451-468.

Jones, D.S., Mueller, P.A., Hodell, D.A., and Stanley, L.A., $1993 .{ }^{87} \mathrm{Sr} /{ }^{86} \mathrm{Sr}$ geochemistry of Oligocene and Miocene marine strata in Florida. In Zullo, V.A., Harris, W.B., Scott, T.M., and Portell, R.W. (Eds.), The Neogene of Florida and Adjacent Regions: Proc. 3rd Bald Head Island Conf. Coastal Plain Geol. Florida Geolog. Surv. Special Publ., 37:15-26.

Mallinson, D.J., Compton, J.S., Snyder, S.W., and Hodell, D.A., 1994. Strontium isotopes and Miocene sequence stratigraphy across the northeast Florida platform. Soc. Econ. Paleontol. Mineral., 64:392-407.

Mallinson, D.J., and Compton, J.S., 1995. Mixed carbonate-siliciclastic sequence stratigraphy utilizing strontium isotopes: Deciphering the Miocene sea-level history of the Florida Platform. In Haq, B.U., (Ed.), 
Sequence stratigraphy and depositional response to eustatic, tectonic, and climate forcing. Kluwer Academic Publishers, Netherlands: 25-58.

McCartan, L., Buursink, M.D., Mason, D.B., Van Valkenburg, S.G., Kistler, R.W., Robinson, A.C., Sugarman, P.J., and Libarkin, J.C., 1995a. Geologic cross sections from Sarasota and Venice to Vero Beach, Florida. Open-File Rep.-U.S. Geol. Surv., 95-821.

McCartan, L., Moy, W.-S., and Bradford, L., 1995b. Geologic map of the Sarasota and Arcadia, Florida $30 \times 60$-minute quadrangles. Open-File Rep.-U.S. Geol. Surv., 95-261.

McCartan, L., and Owens, J.P., 1991. Detrital heavy minerals in surficial sand of the Florida peninsula: research conference on Quaternary coastal evolution field guidebook. SEPM and IGCP Project 274, 91-95.

McCartan, L., Weedman, S,D., Wingard, G.L., Edwards, L.E., Sugarman, P.J., Feigenson, M.D., Buursink, M.L., and J.C. Libarkin, 1995c. Age and diagenesis of the Upper Florida aquifer and the Intermediate aquifer system in southwestern Florida. U.S. Geol. Surv. Bull., 2122.

Miller, K.G., et al., 1994. Proc. ODP, Init. Repts., 150X: College Station, TX (Ocean Drilling Program).

Miller, K.G., et al., 1996a. Proc. ODP, Init. Repts., 150X (Suppl.): College Station, TX (Ocean Drilling Program).

Miller, K.G., Feigenson, M.D., Kent, D.V., and Olsson, R.K., 1988. Upper Eocene to Oligocene isotope $\left({ }^{87} \mathrm{Sr} /{ }^{86} \mathrm{Sr}, \delta^{18} \mathrm{O}, \delta^{13} \mathrm{C}\right)$ standard section, Deep Sea Drilling Project Site 522. Paleoceanography, 3:223-233.

Miller, K.G., Feigenson, M.D., Wright, J.D., and Clement, B.M., 1991a. Miocene isotope reference section, Deep Sea Drilling Project Site 608: an evaluation of isotope and biostratigraphic resolution. Paleoceanography, 6:33-52.

Miller, K.G., and Kent, D.V., 1987. Testing Cenozoic eustatic changes: the critical role of stratigraphic resolution. Cushman Found. Foraminiferal Res. Spec. Publ., 24:51-56.

Miller, K.G., and Mountain, G.S., 1994. Global sea-level change and the New Jersey margin. In Mountain, G.S., Miller, K.G., Blum, P., et al., Proc. ODP, Init. Repts., 150: College Station, TX (Ocean Drilling Program), $11-20$.

Miller, K.G., Mountain, G.S., Blum, P., Gartner, S., Alm Per, G., Aubry, M.P., Burckle, L.H., Guerin, G., Katz, M.E., Christensen, B.A., Compton, J., Damuth, J.E., Deconinck, J.F., de Verteuil, L., Fulthorpe, C.S., Hesselbo, S.P., Hoppie, B.W., Kotake, N., Lorenzo, J.M., McCracken, S., McHugh, C.M., Quayle, W.C., Saito, Y., Snyder, S.W., ten Kate, W.G., Urbat, M., Van Fossen, M.C., Vecsei, A., Sugarman, P.J., Mullikin, L., Pekar, S., Browning, J.V., Liu, C., Feigenson, M.D., Goss, M., Gwynn, D., Queen, D.G., Powars, D.S., Heibel, T.D., and Bukry, D., 1996b. Drilling and dating New Jersey Oligocene-Miocene sequences: ice volume, global sea level, and Exxon records. Science, 271:1092-1095.

Miller, K.G., and Sugarman, P J., 1995. Correlating Miocene sequences in onshore New Jersey boreholes (ODP Leg 150X) with global $\delta^{18} \mathrm{O}$ and Maryland outcrops. Geology, 23:747-750.

Miller, K.G., Thompson, P.T., and Kent, D.V., 1993. Integrated late EoceneOligocene stratigraphy of the Alabama coastal plain: correlation of hiatuses and stratal surfaces to glacioeustatic lowerings. Paleoceanography, $8: 313-331$

Miller, K.G., Wright, J.D., and Fairbanks, R.G., 1991b. Unlocking the Ice House: Oligocene-Miocene oxygen isotopes, eustasy, and margin erosion. J. Geophys. Res., 96:6829-6848.

Opdyke, N.D., Spangler, D.P., Smith, D.L., Jones, D.S., and Lundquist, R.C., 1984. Origin of the epeirogenic uplift of Pliocene-Pleistocene beach ridges in Florida and development of the Florida karst. Geology, 12:226228.

Oslick, J.S., Miller, K.G., and Feigenson, M.D., 1994. Oligocene-Miocene strontium isotopes: stratigraphic revisions and correlations to an inferred glacioeustatic record. Paleoceanography, 9:427-443.
Owens, J.P., Bybell, L.M., Paulachok, G., Ager, T.A., Gonzalez, V.M., and Sugarman, P.J., 1988. Stratigraphy of the Tertiary sediments in a 945foot-deep core hole near Mays Landing in the southeastern New Jersey Coastal Plain. Geol. Surv. Prof. Pap. U.S., 1484.

Owens, J.P., and Sohl, N.F., 1969. Shelf and deltaic paleoenvironments in the Cretaceous-Tertiary formations of the New Jersey Coastal Plain. In Subitzky, S. (Ed.), Geology of Selected Areas in New Jersey and Eastern Pennsylvania and Guidebook of Excursions: New Brunswick, NJ (Rutgers Univ. Press), 235-278.

Owens, J.P., Sugarman, P.J., Sohl, N.F., and Orndorff, R.C., 1995a. Geologic map of New Jersey: Southern Sheet. Open-File Rep.-U.S. Geol. Surv., 95-254.

Owens, J.P., Sugarman, P.J., Sohl, N.F., Parker, R., Houghton, H.H., Volkert, R.V., Drake, A.A., and Orndorff, R.C., 1995b. Geologic map of New Jersey: central sheet. Open-File Rep.-U.S. Geol. Surv., 95-253.

Pazzaglia, F.J., and Gardner, T.W., 1994. Late Cenozoic flexural deformation of the middle U.S. Atlantic passive margin. J. Geophys. Res., 99:12,143$12,157$.

Pekar, S.F., 1995. New Jersey Oligocene sequences recorded at the Leg 150X boreholes (Cape May, Atlantic City, and Island Beach) [Master's thesis]. Rutgers Univ., Piscataway, NJ.

Pekar, S.F., and Miller, K.G., 1996. New Jersey Oligocene "Icehouse" sequences (ODP Leg 150X) correlated with global $\delta^{18} \mathrm{O}$ and Exxon eustatic records. Geology, 24:567-570.

Poag, C.W., and Sevon, W.D., 1989. A record of Appalachian denudation in postrift Mesozoic and Cenozoic sedimentary deposits of the U.S. middle Atlantic continental margin. Geomorphology, 2:119-157.

Scott, T.M., 1988. The lithostratigraphy of the Hawthorn Group (Miocene) of Florida. Florida Geolog. Surv. Bull. 59:1-148.

Scott, T.M., Wingard, G.L., Weedman, S.D., and Edwards, L.M., 1994. Reinterpretation of the peninsular Florida Oligocene: a multidisciplinary view. Geol. Soc. Am. Abstr. Progr., 26:151.

Sugarman, P.J., and Miller, K.G., 1997. Correlation of Miocene sequences and hydrogeologic units, New Jersey Coastal Plain. In Segall, M.P., Colquhoun, D., and Siron, D. (Eds.), Evolution of the Atlantic Coastal Plain-Sedimentology, Stratigraphy and Hydrogeology. Sediment. Geol., 108:3-18.

Sugarman, P.J., Miller, K.G., Owens, J.P., and Feigenson, M.D., 1993. Strontium isotope and sequence stratigraphy of the Miocene Kirkwood Formation, Southern New Jersey. Geol. Soc. Am. Bull., 105:423-436.

Sugarman, P.J., Miller, K.G., Bukry, D., and Feigenson, M.D., 1995. Uppermost Campanian-Maestrichtian strontium isotopic, biostratigraphic, and sequence stratigraphic framework of the New Jersey Coastal Plain. Geol. Soc. Am. Bull., 107:19-37.

Webb, S.D., and Hulbert, R.C., Jr., 1986. Systematics and evolution of Pseudhipparion (Mammalia, Equidae) from the late Neogene of the Gulf Coastal Plain and the Great Plains. Spec. Pap.-Contrib Geol., Univ. Wyoming, 3:237-272.

Webb, S.D., MacFadden, B.J., and Baskin, J.A., 1981. Geology and paleontology of the Love bone bed from the late Miocene of Florida. Am. J. Sci., 281:513-544.

Wingard, G.L., Weedman, S.D., Scott, T.D., Edwards, L.E., and Green, R.C., 1994. Preliminary analysis of integrated stratigraphic data from the South Venice Corehole, Sarasota County, Florida. Open-File Rep.-U.S. Geol. Surv., 95-3, 129 p.

Date of initial receipt: 1 February 1996

Date of acceptance: 7 October 1996

Ms 150XSR-312 